\title{
Document Identification
}

\section{Change Title:}

PRC-STP-00274

Consolidation of $\mathrm{K}$ Basin Sludge Data and Experiences on Agglomerate Formation

\section{Key Words:}

Sludge Treatment Project, K Basin, Agglomerate, Agglomeration, Hardpan

2. Project No.Mork Package No.:

\begin{tabular}{|l|l|l|l|}
\multicolumn{5}{|c}{$S T P$} \\
\hline 3. Area & 4. Building & 5. Facility & 6. System No. \\
100 & $105 \mathrm{KW}$ & NA & STP -72.3 \\
\hline
\end{tabular}

7. Release: $\quad$ Release CACN 300285

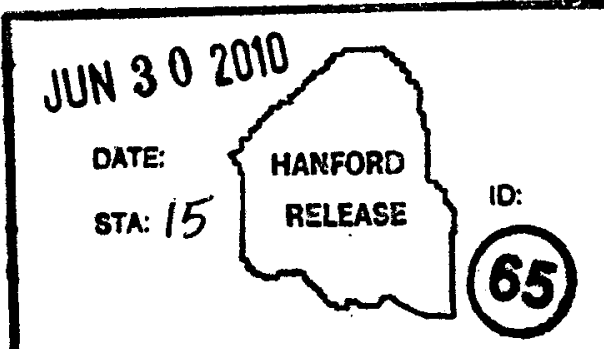

8. USQ Required? $\square$ USQ $\square$ CX $\bigotimes$ NA No.: Per PRC-PRO-062 Section 2, Scope

9. Distribution - Name

R. B. Baker

T. K. Dhaliwal

C. H. Delegard

S. R. Hill

MSIN Distribution - Name

A3-06 R. E. Raymond

A0-26 W. W. Rutherford

P7-25 A. J. Schmidt

A0-26 J. P. Sloughter

A0-26 STP Project File/N. Fouad

M. E. Johnson

10. Change Description (description and reason for requested change):

Incorporated general editorial changes.

Added Figure 10 and associated discussion on uraninite oxidation testing being performed at Pacific Northwest National Laboratory in Section 3.5 pages 21 and 20, respectively.

Revised Conclusions section.

\section{Approvals

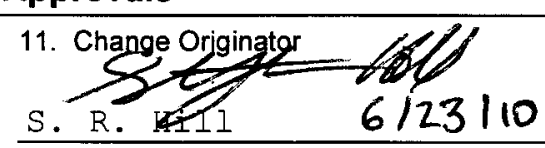

Print/Signature/Date

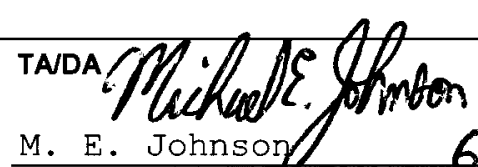

Print/Signature/Date
MSIN

AO-26

A3-06

$\mathrm{P} 8-60$

A $3-06$

H6-08

\begin{tabular}{|c|c|c|c|c|c|c|c|}
\hline Action & Number & \multicolumn{3}{|c|}{ Title } & $\begin{array}{c}\text { Rev (being } \\
\text { issued) }\end{array}$ & $\begin{array}{l}\text { Change } \\
\text { Page(s) }\end{array}$ & $\begin{array}{l}\text { Config. } \\
\text { Baseline }\end{array}$ \\
\hline $\mathrm{DR}$ & PRC-STP-00274 & \multicolumn{3}{|c|}{$\begin{array}{l}\text { PRC-STP-00274 } \\
\text { Consolidation of } \mathrm{K} \text { Basin Sludge Data and } \\
\text { Experiences on Agglomerate Formation }\end{array}$} & 1 & & $\square$ \\
\hline $\mathrm{N}$ & & \multicolumn{3}{|c|}{ Experiences on Agglomerate Formation } & & & $\square$ \\
\hline \multicolumn{8}{|c|}{ 13. Potentially Affected Documents Not Modified By This EDC: } \\
\hline & Document Type & $\begin{array}{l}\text { Document } \\
\text { Number/Revision }\end{array}$ & Document Owner (Organization) & & $\begin{array}{l}\text { cal Authority } \\
\text { Jotified }\end{array}$ & \multicolumn{2}{|c|}{ Date Notified } \\
\hline NA & & $\mathrm{NA}$ & $N A$ & NA & & \multicolumn{2}{|c|}{ NA } \\
\hline
\end{tabular}


PRC-STP-00274

Revision 1

\section{Consolidation of $\mathrm{K}$ Basin Sludge Data and Experiences on Agglomerate Formation}

Prepared for the U.S. Department of Energy

Assistant Secretary for Environmental Management

Contractor for the U.S. Department of Energy under Contract DE-AC06-08RL14788

CH2MHILL

Plateau Remediation Company

P.O. Box 1600

Richland, Washington 99352

Approved for Public Release;

Funther Dissemination Unlimited 
PRC-STP-00274

Revision 1

EDC \#: ECR-10-000587

\section{Consolidation of K Basin Sludge Data and Experiences on Agglomerate Formation}

Document Type: TI

Program/Project: STP

S. R. Hill

CH2M HILL Plateau Remediation Company

Date Published

June 2010

Prepared for the U.S. Department of Energy

Assistant Secretary for Environmental Management

Contractor for the U.S. Department of Energy

under Contract DE-AC06-08RL14788

\section{CH2MHILL}

Plateau Remediation Company

P.O. Box 1600

Richland, Washington
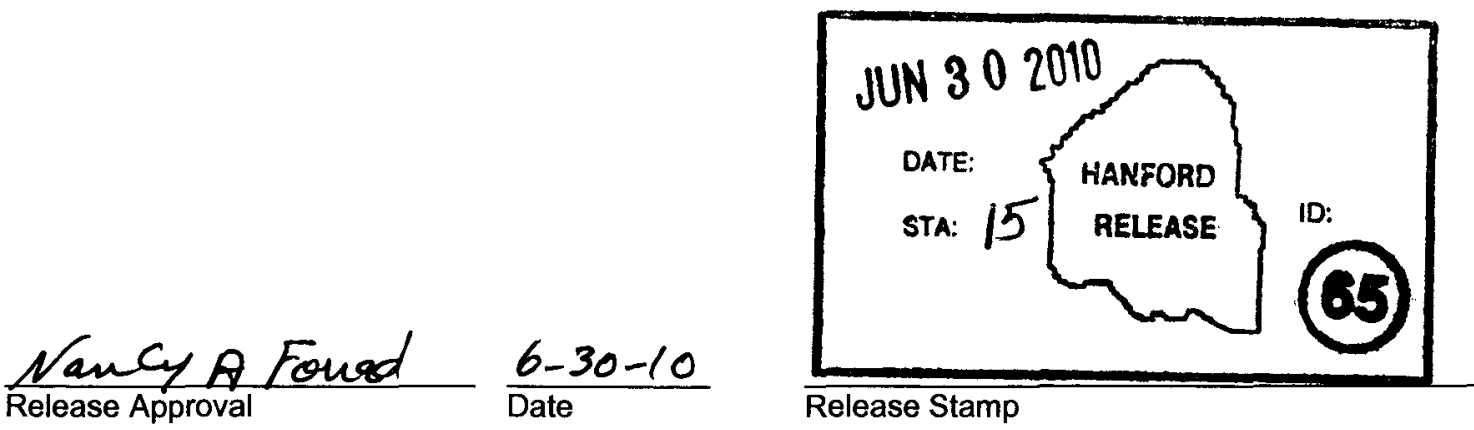
TRADEMARK DISCLAIMER

Reference herein to any specific commercial product, process,

or service by trade name, trademark, manufacturer, or

otherwise, does not necessarily constitute or imply its

endorsement, recommendation, or favoring by the United

States Government or any agency thereof or its contractors or subcontractors.

This report has been reproduced from the best available copy.

Printed in the United States of America

Total Pages: 41 


\section{CHPRC RECORD OF REVISION (ROR)}

(1) Document Number PRC-STP-00274

Page 1 of 2

(2) Title

PRC-STP-00274

Consolidation of $\mathrm{K}$ Basin Sludge Data and Experiences on Agglomerate Formation

\section{Change Control Record}

(3)

Revision

1

Incorporated general editorial changes

Added Figure 10 and associated discussion on uraninite oxidation

1

testing being performed at Pacific Northwest National Laboratory

in Section 3.5 pages 21 and 20 , respectively.

${ }_{1}$ Rg Revised Conclusions section Per ECR-10-000587

(4) Description of Change - Replace, Add, and Delete Pages

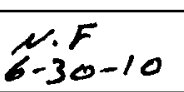

Authorized for Release

(5) DAVTA Date millow 6/23/10

mis.thmon 6/23/10

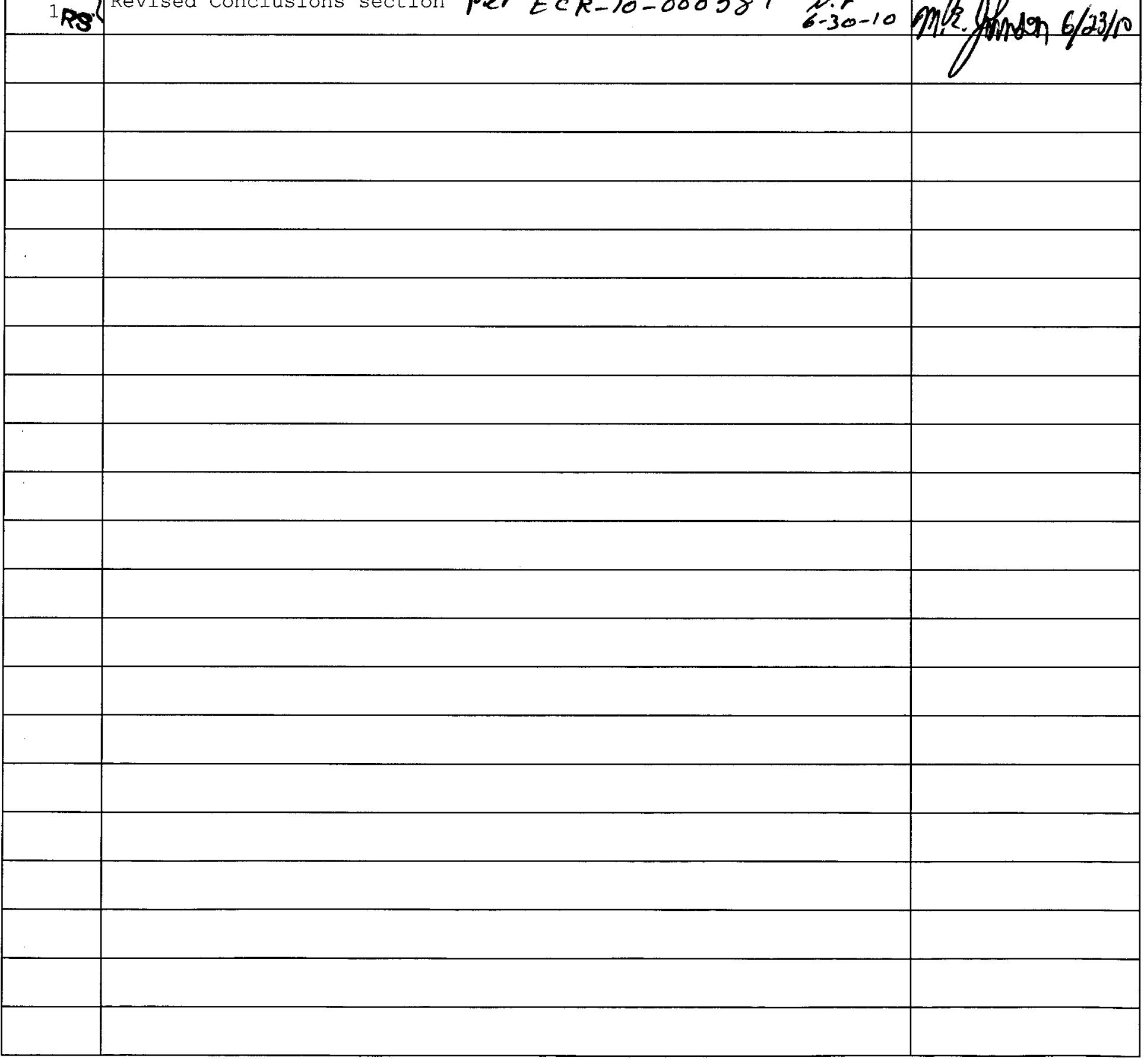




\section{Summary}

The formation of high sludge strength agglomerates is a key concern to the Sludge Treatment Project (STP) to ensure the sludge can be retrieved after planned storage for at least 10 years in Sludge Transport and Storage Containers (STSC) at T Plant. This report addresses observations of agglomerate formation, conditions that the data shows lead to agglomeration, the frequency of agglomerate formation and postulated physiochemical mechanisms that may lead to agglomeration. Although the exact underlying chemistry of $\mathrm{K}$ Basin sludge agglomerate formation is not known, the factors that lead to agglomeration formation, based on observations, are as follows:

- High Total Uranium Content (i.e., sample homogeneity and influence from other constituents)

- Distribution of Uranium Phases (i.e., extent of conversion from uraninite to uranium oxide hydroxide compounds)

- Sample Dry-out (loss of cover water)

- Elevated temperature

- Solubility of U(IV) phases vs. U(VI) phases into water

- Long storage times

Agglomerated sludge has occurred infrequently and has only been observed in four laboratory samples, five samples subjected to hydrothermal testing (performed for 7 to 10 hours at $\sim 185^{\circ} \mathrm{C}$ and $225 \mathrm{psig}$ ), and indirectly during six sampling events in the KE Basin. In the four laboratory samples where agglomerates were observed, the agglomerates exhibited high shear strength and the sample container typically had to be broken to remove the solids. The total uranium content (dry basis) for the four samples (KE Pit, KC-2/3 SS, KC-2/3 M250 and 96-13) were $\sim 8 \mathrm{wt} \%, \sim 59.0 \mathrm{wt} \%, 68.3 \mathrm{wt} \%$ and 82 $\mathrm{wt} \%$. The agglomerates that were present during the six sampling events were undoubtedly disturbed and easily broken apart during sample collection, thus no agglomerates were observed in subsequent laboratory analyses. The highest shear strengths measured for $\mathrm{K}$ Basin sludge samples were obtained after hydrothermal treatment $\left(7\right.$ to $10 \mathrm{hr}$ at $\left.185^{\circ} \mathrm{C}\right)$ of high-uranium-content $\mathrm{KE}$ canister sludge. The unconfined compressive strength of samples from this testing, measured by a pocket penetrometer, infers that their shear strength may be between $120 \mathrm{kPa}$ and $170 \mathrm{kPa}$ (PNNL-16496). These shortduration hydrothermal tests were conducted at temperatures much greater than the temperature of the $\mathrm{T}$ Plant canyon cells $\left(-7^{\circ} \mathrm{C}\right.$ to $\left.33^{\circ} \mathrm{C}\right)$; however, the strength results provide an initial bounding target for sludge stored for many years, and an upper range for simulants (53451-TP02, Rev 0).

Sampling and characterization activities conducted in 2009 have measured the total uranium content and uranium speciation for sludge stored in Engineered Containers SCS-CON-220, -240, -250, and -260 (PNNL-19035). Based on on-going testing that has measured the shear strength of uranium samples containing varying uranium (IV) to uranium (VI) ratios and the characterization of the sludge in Engineered Containers SCS-CON-220, $-240,-250$, and -260 , it is unlikely that agglomerates will form on a large scale in this sludge. The highest measured total uranium concentration in the Engineered Container SCS-CON-220 sludge is $35.2 \mathrm{wt} \%$ and only $4 \mathrm{wt} \%$ to $6 \mathrm{wt} \%$ (dry) in Engineered Containers SCS-CON -240, -250, and -260. The uranium concentrations in Engineered Containers SCS-CON-220, $-240,-250$, and -260 sludge are below the observed threshold of $59 \mathrm{wt} \%$ (dry) for agglomerate formation. Settler sludge however is estimated to contain $\sim 80 \mathrm{wt} \%$ (dry) total uranium, which could lead to the formation of high strength agglomerates depending on the relative concentrations of U(IV) and U(VI) compounds. 
One of the chief concerns of the STP is sludge dry-out. Samples archived in PNNL hot cells have been known to dry out and form hard clods of material, which are then difficult to reconstitute with water (HNF-6705). In 1996, all but one of the samples archived at the 222-S Laboratory dried out. These samples were composed of sludge collected from the KE Basin floor and Weasel Pit. However, in the STP's current design plans for sludge stored in STSCs at T Plant, there are provisions for continual water level observation and periodic water replenishment when needed, which will lower the risk of a dry-out event.

Recent 2009 KE Engineered Container sludge and KW Engineered Container sludge physical characterization have provided some opportunistic data on the behavior of dried sludge (PNNL-19035). As shown in section 5 of this report, sub-samples of sludge core samples taken from Engineered Container 220 that have inadvertently dried after characterization activities indicate that the sludge is mostly composed of very "weak" and friable solids. Since Engineered Container SCS-CON-220 sludge has the highest total uranium (uranium metal and uranium oxide) concentration of the four Engineered Containers sampled to date, if a dry-out event should occur in the STSC while stored at T Plant there is qualitative evidence to suggest that the solids would be "weak" and friable in nature and thus easily mobilized. Information will need to be obtained during the FY 2011 planned characterization of Settler sludge to determine characteristic of this sludge upon drying as well as total uranium concentration to ascertain propensity for agglomeration. 
Acronyms/Abbreviations:

$d_{p}$

NLOP

PNNL

SEM

SNF

STP

TEM

UOH

XRD
Particle Diameter

North Loadout Pit

Pacific Northwest National Laboratory

Scanning Electron Microscopy

Spent Nuclear Fuel

Sludge Treatment Project

Transmission Electron Microscopy

Uranyl Oxide Hydrate

$\mathrm{X}$-Ray Diffraction

\section{Mineral Chemical Formulas:}

\begin{tabular}{|c|c|}
\hline Albite & $\mathrm{NaAlSi}_{3} \mathrm{O}_{8}$ \\
\hline Gismondine & $\mathrm{CaAlSi}_{2} \mathrm{O}_{8} \cdot 4 \mathrm{H}_{2} \mathrm{O}$ \\
\hline Becquerelite & $\mathrm{Ca}\left(\mathrm{UO}_{2}\right)_{6} \mathrm{O}_{4}(\mathrm{OH})_{6} \cdot 8\left(\mathrm{H}_{2} \mathrm{O}\right)$ \\
\hline Meta-Schoepite & $\begin{array}{l}\text { Formula }=\mathrm{UO}_{3} \cdot 2 \mathrm{H}_{2} \mathrm{O} \\
\text { Phase }=\left(\mathrm{UO}_{2}\right)_{4} \mathrm{O}(\mathrm{OH})_{6} \cdot 5 \mathrm{H}_{2} \mathrm{O}\end{array}$ \\
\hline Schoepite & $\begin{array}{l}\text { Formula }=\mathrm{UO}_{3} \cdot 2.25 \mathrm{H}_{2} \mathrm{O} \\
\text { Phase }=\left(\mathrm{UO}_{2}\right)_{4} \mathrm{O}(\mathrm{OH})_{6} \cdot 6 \mathrm{H}_{2} \mathrm{O}\end{array}$ \\
\hline Uraninite & $\mathrm{UO}_{2}, \mathrm{U}_{4} \mathrm{O}_{9}$, and $\mathrm{U}_{3} \mathrm{O}_{7}$ \\
\hline Uranophane & $\mathrm{Ca}\left(\mathrm{UO}_{2}\right)_{2}\left(\mathrm{SiO}_{3} \mathrm{OH}\right)_{2} \cdot 5 \mathrm{H}_{2} \mathrm{O}$ \\
\hline
\end{tabular}




\section{Table of Contents}

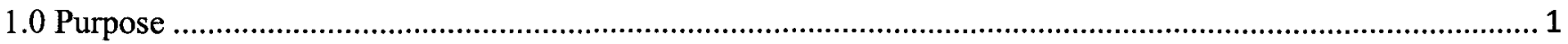

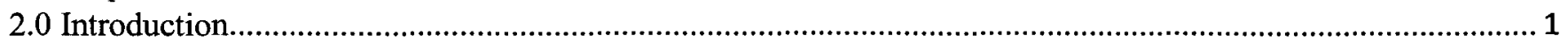

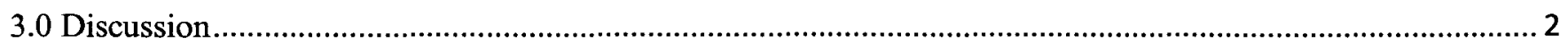

3.1 Observations of Agglomerates in Storage and Testing.................................................................. 2

3.2 Observations of Hardpan Layers in K Basin Sludge Sampling Campaigns ........................................7

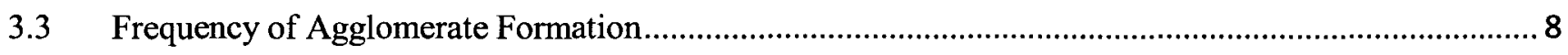

3.4 Conditions that Lead to the Formation of Agglomerates............................................................ 11

3.5 Postulated Physical and Chemical Mechanisms of Agglomerate Formation ....................................... 14

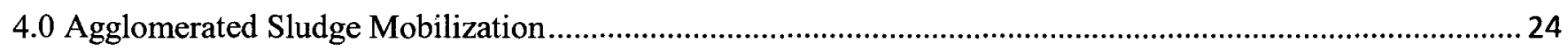

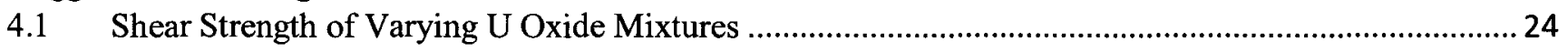

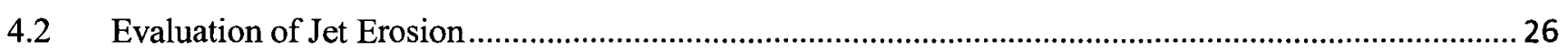

5.0 Physical Properties of Dried KE Engineered Container sludge and KW Engineered Container sludge ...........28

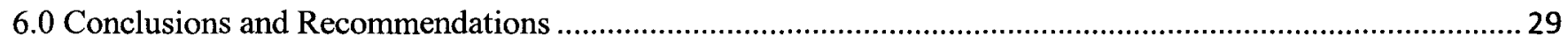

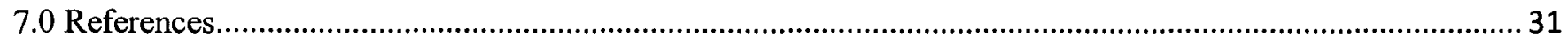

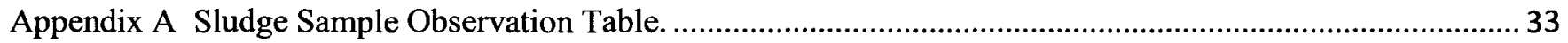

\section{List of Figures}

Figure 1 Agglomerated Sample 96-13

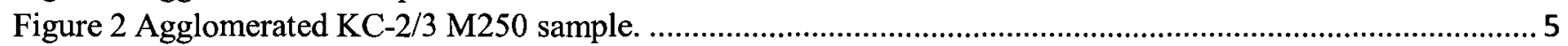

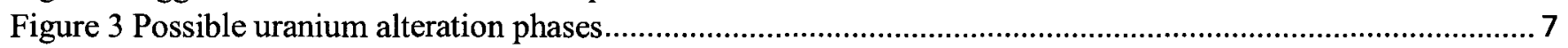

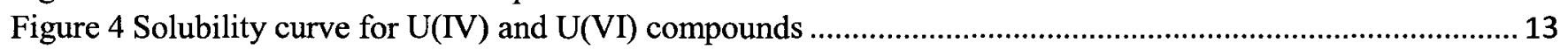

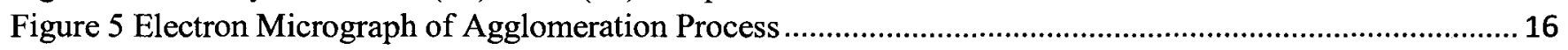

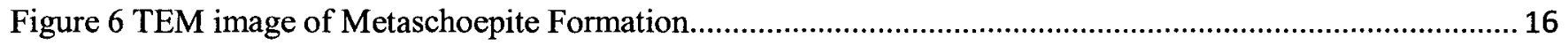

Figure 7 Agglomeration of UOH fractal aggregates at the air-water interface ................................................ 17

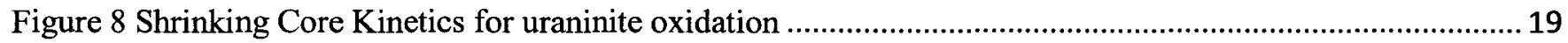

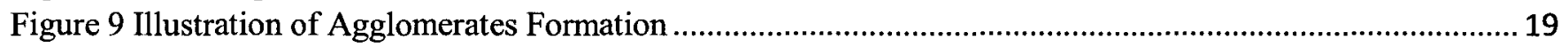

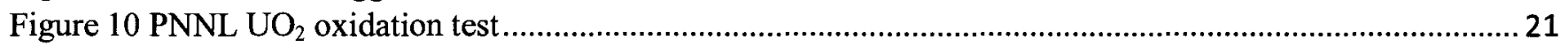

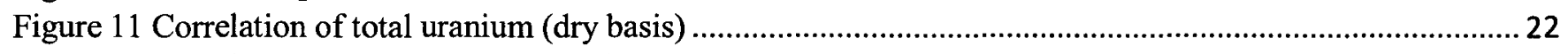

Figure 12 Correlation of Shear Strength with U(VI) concentration (Dry basis)...............................................26

Figure 13 Post-Test Examination of Physical Property Samples from SCS-CON-220 Core Samples .................. 28

\section{List of Tables}

Table 1 Summary of Sludge Samples of K Basins Sludge that have been collected...........................................9

Table 2 Sludge Archive Samples for Compositing, Re-Jarring, Blending and Inventory ................................... 10

Table $3 \mathrm{KW}$ Engineered Container sludge dry weight \% total uranium............................................................. 20

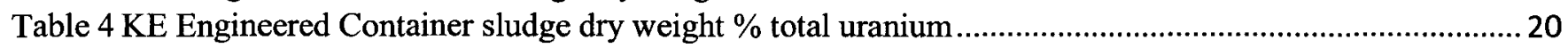

Table 5 Uranium Speciation Data by Engineered Container Core Composite Sieve Fraction..............................2 21

Table 6 Results of mixed oxide shear strength in a pure uranium system .......................................................... 25 


\subsection{Purpose}

The purpose of this document is to consolidate existing data associated with the formation of high strength K Basin sludge agglomerates, as discussed in Sludge Treatment Project Engineered Container Retrieval and Transfer System Technology Maturation Plan (PRC-STP-00113, pg 33). A separate report will be issued to address sludge chemistry and rheology information on identified sludge aging mechanisms that lead to agglomeration and / or changes in rheology. Information on sludge agglomerate formation will be used to prepare simulants and conduct testing of equipment to demonstrate the ability to remove sludge from a STSC after interim storage in T Plant. Past observations have indicated that agglomerate formation was one of the key concerns with $\mathrm{K}$ Basin sludge stored in water filled containers. In this report, the observations of agglomerate formation, conditions that are believed to lead to agglomeration and postulated physical and chemical mechanisms by which sludge agglomeration occurs are discussed. These key subjects are investigated using available quantitative data and observations collected during sludge testing and sampling campaigns.

\subsection{Introduction}

Agglomeration of K Basin sludge particles is of particular interest to the Sludge Treatment Project (STP) due to the expected long-term storage in water filled Sludge Transport and Storage Containers (STSCs) in T-Plant canyon cells for at least 10 years. T Plant will be used as interim storage while the STP considers final treatment methods for disposing of the $\mathrm{K}$ Basin sludge as remote-handled transuranic waste. Thus, it is important to understand the effects of long-term storage (e.g., agglomeration/compaction, rate of oxidation, volumetric expansion, etc) will have on the $\mathrm{K}$ Basin sludge in order to prepare for sludge retrieval prior to treatment and disposal after the prescribed storage period. The focus of this report is to consolidate available information that has been collected regarding agglomerate formation in $\mathrm{K}$ Basin sludge. For this report agglomerates will be defined as sludge of sufficient strength such that mobilization and transfer of the sludge is significantly impeded (i.e., requires sample container to be disassembled/fractured to facilitate sample recovery).

The sludge storage conditions in the STSC at T Plant will differ significantly from that of the KW Basin pool. In the basin pool water is chilled $\left(10^{\circ} \mathrm{C}\right.$ to $\left.15^{\circ} \mathrm{C}\right)$, filtered (sand filter) and passed through ion exchange beds (containing both anion and cation exchange media). As a result, the $\mathrm{KW}$ Basin pool pH has been near neutral ( 4.6 to 6.0$)$ and the conductivity has been low $(1.15 \mu \mathrm{S} / \mathrm{cm}$ to $2.80 \mu \mathrm{S} / \mathrm{cm})$, as measured between February 2008 and February 2010. The T Plant canyon temperatures ranges from $7^{\circ} \mathrm{C}$ to $32^{\circ} \mathrm{C}$ depending on the ambient external weather conditions (HNF-SD-SNF-TI-015, Vol 2, Rev 14A, Table 4-25). However, the temperature swing in the T Plant storage cells is expected to be less severe due to the cells being partially below ground, the thermal mass of the massive concrete structure, along with the insulating properties of the thick concrete cell walls and ground. Once loaded into the STSCs, the sludge and supernatant will be essentially a closed system, with the STSCs vented to the T Plant cell air atmosphere. Unlike the $\mathrm{KW}$ Basin pool, the $\mathrm{pH}$ and conductivity of the supernatant in contact with sludge in a STSC will not be controlled while the STSC is in storage at T Plant, which could affect sludge physical properties. 
The sludge storage conditions in the PNNL hot cells are similar to the storage conditions anticipated at $\mathrm{T}$ Plant and better predictors of sludge behavior in STSCs than the in-basin observations. Therefore, observations of sludge samples and uranium oxide samples during testing and storage in the PNNL hot cells are the primary relevant source of information used in this report to assess agglomerate formation during sludge storage in a STSC.

\subsection{Discussion}

Prior to June 2010, PNNL did not have a procedure nor was instructed to systematically evaluate sludge samples during storage to evaluate the various conditions that effect the formation of high strength sludge agglomerates. In June 2010, PNNL issued a test instruction for evaluating sub-samples from the FY2009 sludge characterization for changes in physical properties during long term storage (Shimskey 2010). Observations of sludge samples discussed here are based on a limited subset of samples that were removed from hot cell storage and used for various tests and the achieve sample evaluations conducted in 2007 (PNNL-17078). These sludge samples had been stored in PNNL hot cells for as many as $\sim 8$ years and provide an important source on sludge aging behavior. This section consolidates observations of sludge agglomeration and correlates this information with sludge properties and storage conditions.

\subsection{Observations of Agglomerates in Storage and Testing}

The most relevant study of sludge behavior during storage, and a significant instance of agglomeration among samples collected from the KE Basin occurred during a 28-month (May 2002 to September 2004) sludge compaction test performed by PNNL at hot cell conditions (i.e., $25^{\circ} \mathrm{C}$ to $35^{\circ} \mathrm{C}$ and a slight vacuum). The test population consisted of six $\mathrm{KE}$ Basin sludge samples with test identification numbers 96-13, FE-5, KC-2/3 whole, KC-4, KC-5, and SNF Comp (PNNL-15092). The six samples were collected from the KE Basin during sampling campaigns that took place in FY 1996 and FY 1999. The 96-13 sample was collected from KE Cubicle 5055 from the West Canister Barrel (HNF-SP-1201, pg 26); the other samples were composite samples, made up from sludge collected from multiple locations in the KE Basin. Appendix A provides relevant analytical information, such as starting and ending uranium phases, total uranium content and identity (i.e., location of collection) for these samples. The testing was performed to quantify the amount of sludge compaction and loss of supernatant that can be expected during long-term storage at T Plant.

In preparation for the compaction and evaporation test, the six samples were placed in graduated cylinders and excess KE Basin water was added to cover the sludge. The addition of KE Basin water was performed periodically during the 28 -month compaction and evaporation test to ensure the sludge was covered at all times. Of the six samples in the study, only sample 96-13 which is composed of sludge collected from a single fuel storage canister (canister constructed of aluminum, containing fuel in poor condition) showed significant formation of high strength agglomerates and actually self-cemented in the graduated cylinder, as seen in Figure 1. The agglomeration and self-cementation was so severe, the glass graduated cylinder had to be broken with the hot cell manipulator arm to recover the sample. The sample was then sheared into pieces with considerable, but not quantified force by the manipulator arm and analyzed. The remaining five samples (FE-5, KC-2/3 whole, $\mathrm{KC}-4, \mathrm{KC}-5$, and SNF Comp) were readily re-suspended in their respective supernatant at the conclusion of the 28 -month study, and there was no evidence of agglomerate formation. 
It must be noted that upon completion of this test, sample 96-13 was sheared into small chunks and stored in water within jars in 2004. The sample was then re-examined in July 2009, where the well defined agglomerates that were present $\sim 6$ years earlier had collapsed to form a puck at the container bottom, with the material having undergone oxidation [from blue/black, indicative of U(IV) phases, to green/yellow, indicative of $\mathrm{U}(\mathrm{VI})$ phases] ${ }^{1}$.

In addition, prior to the 28-month Compaction and Evaporation test, sample 96-13 experienced a complete loss of supernatant despite efforts to keep sludge samples covered with water at all times. Six months prior to the initiation of the 28-month test, sample 96-13 was reconstituted by addition of water and mixing. In addition to the dry-out and agglomeration experienced by sample $96-13$, gas bubbles were observed once in the supernatant of this sample during the compaction and evaporation study indicating that oxidation was ongoing and uranium metal was present (PNNL-15092, pg 3.1.2). The presence of hydrogen gas evolving from the reaction of uranium metal and water was speculated to be the cause for discontinuities (i.e., visually interpreted as voids) seen in the sludge sample in Figure 1. Uranium metal oxidation generates heat as a reaction by-product, which may have contributed to the previous loss of supernatant from the sample.
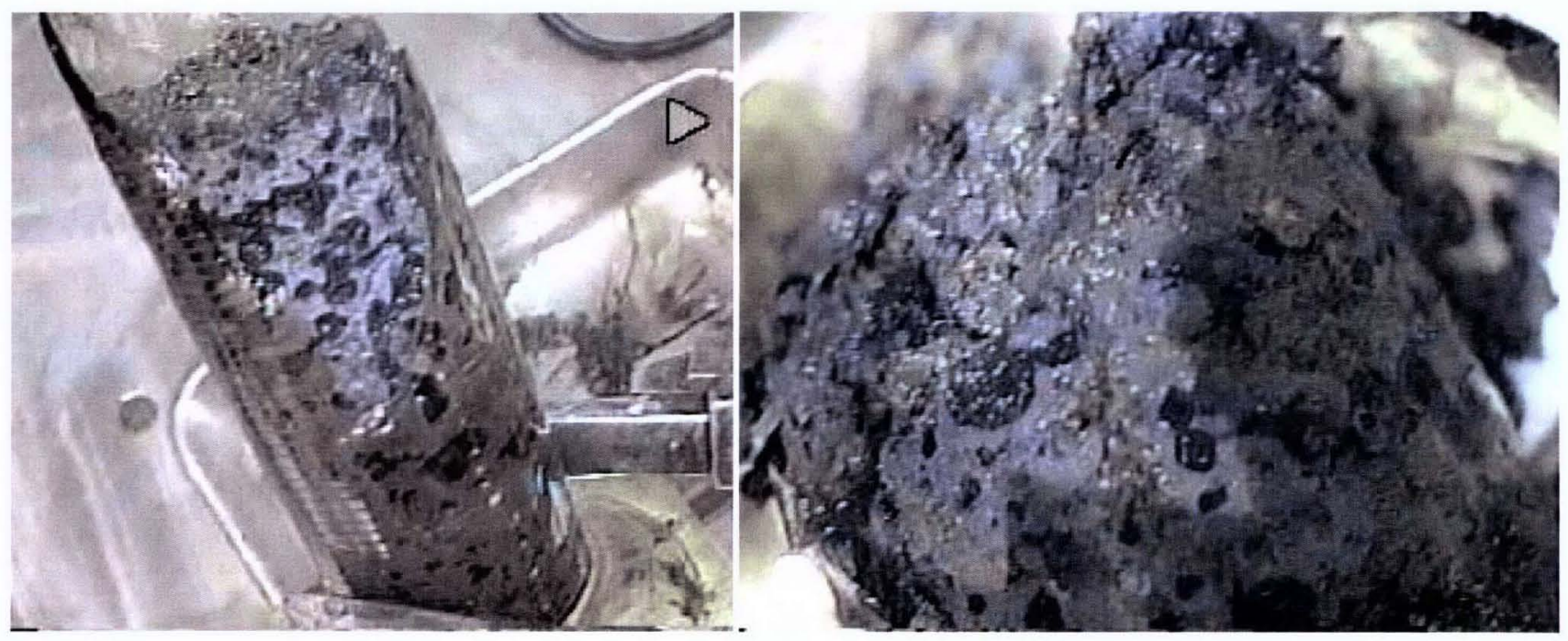

Figure 1 Agglomerated Sample 96-13

Left photo is sample in a $3.5 \mathrm{~cm}$ inner diameter graduated cylinder after settling test and right photo is sample after being removed from the graduated cylinder ${ }^{2}$.

\footnotetext{
${ }^{1}$ July 2009 Monthly Status Report For PNNL Contracts Providing Technical Support to K Basin Closure and Sludge Treatment Projects, Pacific Northwest National Laboratory, Richland WA

${ }^{2}$ Figure courtesy of PNNL-15092, pg 3.10
} 
Significant gas generation was observed in the SNF Comp sample (KE floor and canister sludge + fuel fragments), however agglomerates were not observed during this testing. No gas generation was observed in samples $\mathrm{FE}-5, \mathrm{KC}-2 / 3$ whole, $\mathrm{KC}-4$, or $\mathrm{KC}-5$, during the testing, even though sample $\mathrm{KC}$ $2 / 3$ whole was previously determined to have a uranium metal content of $\sim 1.9 \mathrm{wt} \%$ (PNNL-13320).

Sample 96-13 was found to have uncharacteristically high total uranium content (82 wt\%-dry) compared to the KE Engineered Container or KW Engineered Container sludge that will be stored in the STSCs at T Plant. Two other samples, KC-2/3 whole and SNF Comp, also had relatively high total uranium concentrations of $59.0 \mathrm{wt} \%$ (dry) and $60.2 \mathrm{wt} \%$ (dry), respectively, but they did not experience the formation of high strength agglomerates or undergo self-cementation.

X-ray diffraction (XRD) analyses (HNF-SP-1201, pg 29, Table 3.4) performed about 5 years prior to the Compaction and Evaporation testing indicate that the primary uranium compounds present in sample 96-13 in 1997 were tetravalent uraninites of the formula $\mathrm{UO}_{2}, \mathrm{U}_{4} \mathrm{O}_{9}$, and $\mathrm{U}_{3} \mathrm{O}_{7}$. XRD analysis on $\mathrm{KC}$ $2 / 3$ whole indicated the presence of tetravalent uraninites $\left(\mathrm{U}_{4} \mathrm{O}_{9}\right.$, ) with some schoepite (PNNL-13320). $\mathrm{XRD}$ analyses were not performed immediately before the start of the compaction study. Therefore, the uranium compounds present at the initiation of the Compaction and Evaporation test are not precisely known. Subsequent XRD analyses performed in FY 2007, 3 years after the Compaction and Evaporation study, indicate that the uraninite compounds in samples $96-13$ and $\mathrm{KC}-2 / 3$ whole had oxidized to metaschoepite and schoepite, both of which are UOH compounds (PNNL-17078). No uranium phases were identified in sample KC-5. Sample SNF-Comp contained a combination of KE floor and canister sludge, plus uranium metal, and likely contained some tetravalent uraninites. Samples FE-5, KC-4, were not analyzed by XRD at the time of collection, so the phases present at that time are not available for comparison. The results from XRD scans for the samples analyzed after long-term storage of up to 8 years in the PNNL hot cells demonstrate that the tetravalent uraninite compounds have undergone oxidation to form hexavalent $\mathrm{UOH}$ compounds (i.e., schoepite and metaschoepite and in some cases becquerelite, and uranophane) as seen in Appendix A.

Similar to sample 96-13, sample KC-2/3 M250 also exhibited agglomeration and self-cemented at PNNL hot cell temperatures $\left(25^{\circ} \mathrm{C}\right.$ to $\left.35^{\circ} \mathrm{C}\right)$. Sample $\mathrm{KC}-2 / 3 \mathrm{M} 250$ is a subsample of $\mathrm{KC}-2 / 3$ whole (KE Canister sludge composite used in the Compaction and Evaporation testing) and was prepared by wet-sieving sample $\mathrm{KC}-2 / 3$ whole to provide a sludge fraction that is $<250 \mu \mathrm{m}$, prior to being stored in the PNNL hot cells from 1999 to 2007 , a period of $\sim 8$ years. This sample was discovered to have agglomerated and self-cemented in its storage jar in 2007 when it was planned for use in Hydrothermal testing as a surrogate for Settler sludge. Sample KC-2/3 M250 was also found to have a relatively high total uranium content of $68.3 \mathrm{wt} \%$ (dry). Similar to sample 96-13, sample KC-2/3 M250 exhibited significant strength and could not be retrieved from the storage jar without breaking it (PNNL-16496, pg 2.3). The sample was removed from the broken jar in one cemented rigid column and subsequently sheared into pieces before being blended (homogenized). As seen in Figure 2 (a), sample KC-2/3 M250 looks very similar to sample 96-13 (Figure 1). This sample was analyzed by XRD and the main phases present were identified as hexavalent uranium compounds schoepite and metaschoepite. 
PRC-STP-00274, revision 1

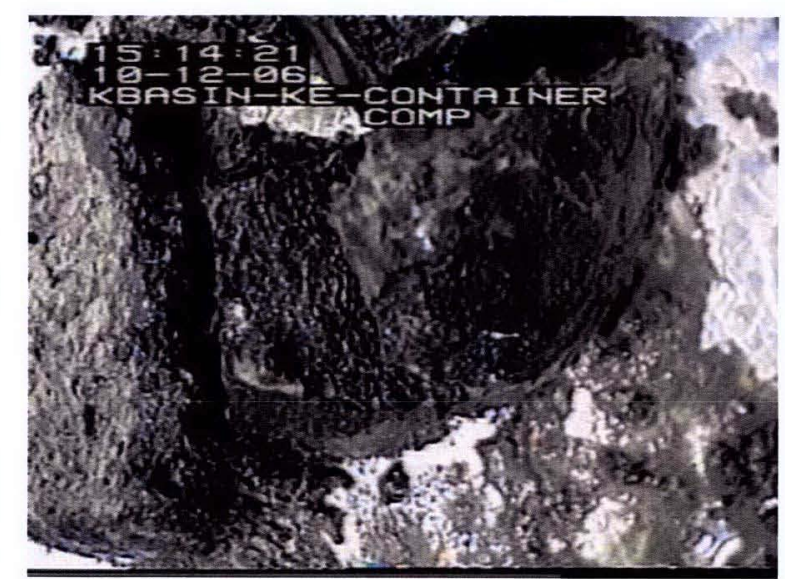

(a)

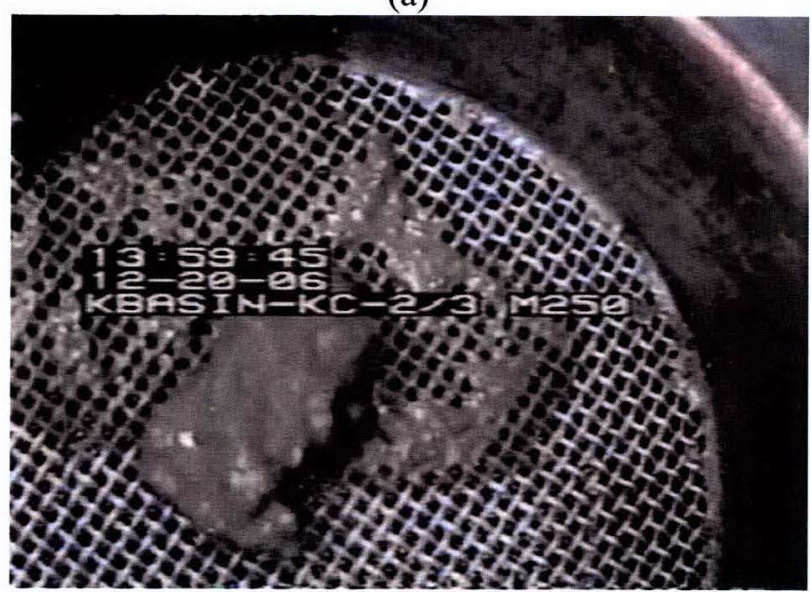

(b)

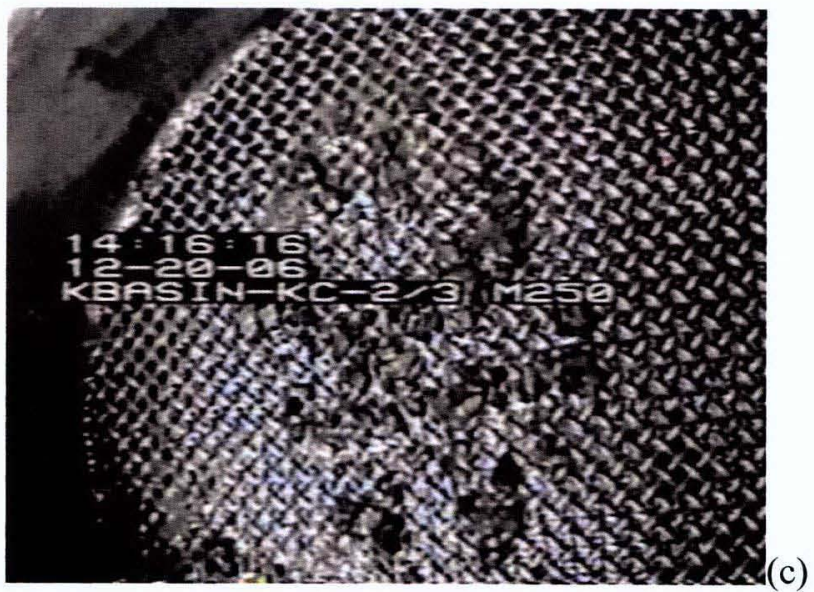

Figure 2 Agglomerated KC-2/3 M250 sample.

(a) Agglomerated KC-2/3 M250 sample after being removed from the graduated cylinder. (b) $6 \mathrm{~g}$ sub-sample of $\mathrm{KC}-2 / 3 \mathrm{M} 250$ after homogenization prior to wet sieving. (c) After sieving the $6 \mathrm{~g}$ sample and washing with water, agglomerates $1000 \mu \mathrm{m}$ to $3000 \mu \mathrm{m}$ can be seen on the $1000 \mu \mathrm{m}$ screen $^{3}$.

\footnotetext{
${ }^{3}$ Figure courtesy of PNNL-16496, pg 2.4
} 
In an attempt to understand the effectiveness of the homogenization and the size of remaining agglomerates, a $6 \mathrm{~g}$ sub-sample of the agglomerated $\mathrm{KC}-2 / 3 \mathrm{M} 250$ sludge (after the parent sample was homogenized with a blender) was wet-sieved with $500 \mu \mathrm{m}$ and $1000 \mu \mathrm{m}$ screens, as seen in Figure 2 (b). Several large agglomerates, $1000 \mu \mathrm{m}$ to $3000 \mu \mathrm{m}$ in diameter were retained on the $1000 \mu \mathrm{m}$ screen as seen in Figure 2 (c). These agglomerates however disintegrated easily with slight pressure from a flexible plastic pipette and therefore would be expected to have negligible shear strength (PNNL-16496, pg 2.3).

Sample KC-2/3 SS (the settled solids fraction of $\mathrm{KC}-2 / 3$ whole consisting of $59.0 \mathrm{wt} \% \mathrm{U}$ total on a dry basis) experienced agglomeration while in PNNL hot cell storage. Like samples $96-13$ and $\mathrm{KC}-2 / 3$ $\mathrm{M} 250$, the sample jar had to be broken to extract the sludge sample. Unfortunately, no XRD analysis could be located for sample KC-2/3 SS.

Sample KE Pit (Weasel Pit sludge) also experienced agglomeration while in storage in the PNNL hot cells. Like the three previous samples (96-13, KC-2/3 M250 and KC-2/3 SS), the sample jar had to be broken to remove the sludge. The KE Pit sample is a composite of sludge samples obtained from the KE Basin Weasel Pit and is estimated to contain $8 \mathrm{wt} \%$ total uranium (dry) (PNNL-17078, Table 7). To prepare the sample individual KE Basin Weasel Pit samples were dried and mixed with water to form this composite.

XRD analyses performed in 1995 found no crystalline uranium phases present in sample KE Pit, however other crystalline phases (quartz, albite, lepidocrocite, goethite, calcite, talc, rutile, and gismondine) were observed. KE Basin historical knowledge and XRD results of KE Weasel Pit sample KES-H-08 (WHC-EP-0877) support the presence of mordenite (chemical name for Zeolon-900 ion exchange material). Even though mordenite was not detected in the KE Pit sample, the zeolite compounds albite $\left(\mathrm{NaAlSi}_{3} \mathrm{O}_{8}\right)$ and gismondine $\left(\mathrm{CaAl}_{2} \mathrm{Si}_{2} \mathrm{O}_{8} \cdot 4 \mathrm{H}_{2} \mathrm{O}\right)$ were detected. These two zeolite phases could have originated from the ion exchange material (mordenite), as it is known to dissolve and re-precipitate in different chemical forms under alkaline conditions (PNNL-12108). This is significant because poor water quality in the KE Basin during the years prior to the collection of the KE pit sample could have caused the basin water to become alkaline (WHC-EP-0877). Therefore, the presence of these phases may explain why sample KE Pit formed agglomerates when no uranium crystalline phases (e.g., metaschoepite and schoepite) were detected. It should be noted that amorphous uranium phases could also have been present at the time of testing, since they would not be detected by XRD.

Other instances of high strength agglomerate formation have been observed during hydrothermal testing with $\mathrm{K}$ Basin sludge samples performed in 2007. As a part of the hydrothermal testing, five sludge samples were subjected to hydrothermal corrosion via step-wise heating and pressure increases over a period of 7 hours to 72 hours until target conditions of $185^{\circ} \mathrm{C}$ and 225 psig were achieved. The five tests used sludge samples composed of the following constituents:

- Test 1: Fine KE Canister Sludge and Fine Uranium Metal Fuel Particles

- Test 2: Fine KE Canister Sludge Composite and Uranium Metal Coupons

- Test 3: KE Container Sludge + Flocculant + Fuel Particles

- Test 4: KE Container Sludge + Flocculant

- Test 5: KE Container Sludge + Organic Ion Exchange Resin Beads

Even though the hydrothermal testing conditions (temperature and pressure) far exceeded what the KE Engineered Container sludge, KW Engineered Container sludge, or Settler sludge will be subjected to 
while stored at $\mathrm{T}$ Plant, the testing does provide some valuable information about the uranium alteration phases that can be produced at elevated temperatures. The diagram below (Figure 3 ) shows the possible uranium phases that can be produced when treated at elevated temperatures $\left(\sim 185^{\circ} \mathrm{C}\right)$ in addition to when stored at hot cell conditions $\left(\sim 25^{\circ} \mathrm{C}\right.$ to $\left.35^{\circ} \mathrm{C}\right)$. The maximum storage temperature at $\mathrm{T}$ Plant is similar to that in the PNNL hot cells, therefore the same uranium phases can be expected to form in sludge stored in STSCs at T Plant as those indicated by the solid reaction pathways; i.e. uraninite, metaschoepite and becquerelite. The dashed reaction pathways show uranium compounds formed under elevated temperatures and are not likely to form in sludge stored in STSCs at T Plant.

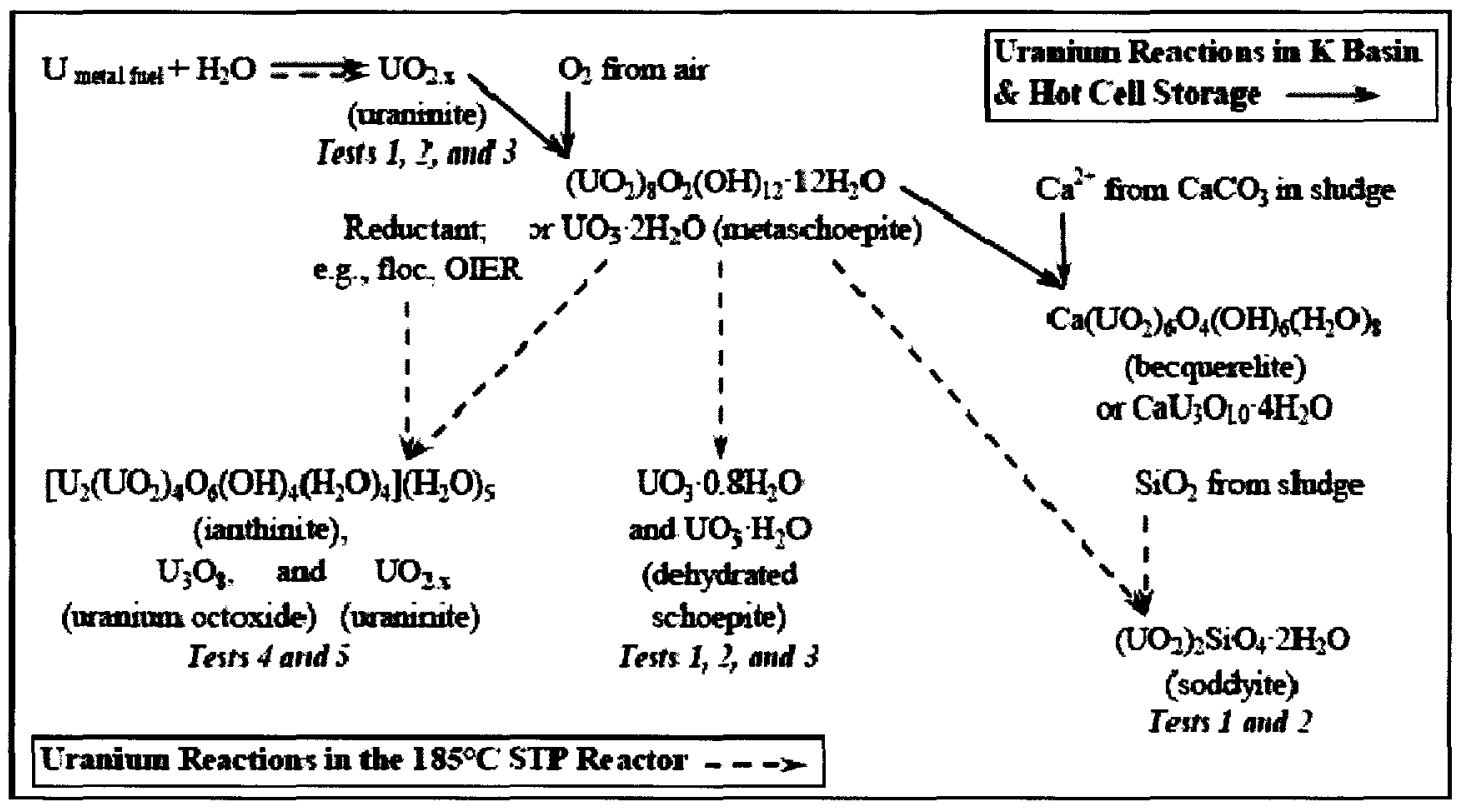

Figure 3 Possible uranium alteration phases ${ }^{4}$

\subsection{Observations of Hardpan Layers in K Basin Sludge Sampling Campaigns}

Agglomerated sludge has been observed six times in the KE Basin during the FY 1995 and FY 1999 sampling campaigns in both the Weasel Pit and NLOP locations. The agglomerated sludge was reported as "hardpan" or "hard packed" material. Three cases of "hardpan" or "hard packed" material of sludge were observed in the 1995 sampling campaign and discussed in WHC-SP-1182. Three additional cases of "hardpan" material were observed in 1999 and are discussed in HNF-4746.

In 1995, "hard packed" material was observed while collecting sludge samples KES-R-18, KES-S-19 and KES-T-20 from the Weasel Pit. The "hard packed" material however was broken up easily in all three cases and the samples were collected without difficulty. During the collection of samples from the Weasel Pit in 1999, one of the sampling isolation tubes could not penetrate a layer of material at a sludge depth of 9-inch, while collecting sample KE-9. The basin floor was known to be another 2-ft down (HNF-4746, pg 5). It is not clear whether this impenetrable layer was a result of hardpan

\footnotetext{
${ }^{4}$ Figure courtesy of PNNL-16496, pg 3.23.
} 
formation or simply the case of equipment (pumps, piping, etc.) buried in the sludge. In another instance, layers of hardpan material were found at a level of $1 / 2$-inch from the Weasel pit floor while collecting sample KE-10 in 1999 (HNF-4746, pg 5). Another observation of hardpan occurred when sampling with isolation tubes in the center of the NLOP in 1999. It was observed that the last 10-inch of sludge was "crusty", while collecting sample KE-5 (HNF-4746, pg 5).

While evidence suggests the presence of agglomerates in these six samples, upon collection the agglomerates were undoubtedly disintegrated and thus were not observed during subsequent laboratory analyses. Furthermore, it is unclear whether the formation of hard layers or hardpans observed when sampling in the KE Basin have any relation to the agglomerates seen in archived samples or sub-samples used for testing. No data suggest that the formation of hardpans in the Basins is directly linked to the formation of agglomerates of hexavalent $\mathrm{UOH}$ particles that has occurred in the PNNL hot cells. These two phenomena (i.e., "hardpan" and "hard packed" layer formation and agglomeration of $\mathrm{UO}_{2}$ oxidation products) may be two entirely separate instances of anomalous KE Basin sludge behavior.

Recent $2009 \mathrm{KW}$ and KE Engineered Container sludge sampling shows no evidence of significant agglomerate or "hard pan" formation. Only slight resistance was encountered when inserting the isolation tube in Engineered Container 220 sludge.

\subsection{Frequency of Agglomerate Formation}

A total of 88 core samples have been collected from the K Basins since 1993, 77 of which were collected before sampling activities in 2009. The remaining 11 core samples were collected from the KW Engineered Containers in 2009. Many of these samples were sub-sampled and/or combined into composite samples for various tests and analyses. The sludge core samples collected in 2009 have not had sufficient time to age and form agglomerates and therefore are not included in the frequency of agglomerate formation analysis.

A summary of the samples collected from the K Basins between 1993 and 2009 is provided in Table 1. Sample material collected from the KE NLOP in 1993 was not archived and provides little insight into sludge agglomeration over time. The samples collected between 1995 and 2009 were sub-divided in the analytical laboratories (either 222-S Laboratory or the Radiological Processing Laboratory), and a significant number of these sample splits were placed into archive storage. In some cases, multiple sample splits were made from parent sample materials (e.g., parent sample KC-2/3 from 1999 has been divided into more than 10 sub-samples).

A systematic assessment of all $\mathrm{K}$ Basin sludge samples for evidence of agglomeration has not been performed. However, in 2007, a large number of archive samples were examined, disturbed (i.e., moved during examination), and repackaged as part of an effort to create larger quantities of test material. Table 2 was compiled from the results of the 2007 sludge sample and sub-sample inspection (PNNL17078). Table 2 shows the samples that have formed high strength agglomerates (highlighted in red) while stored in PNNL hot cells along with their respective origins. Of the 77 samples ( 88 total samples minus 11 samples obtained in 2009) considered, only 4 samples (96-13, KC-2/3 M250, KC-2/3 SS and KE Pit) or composited sub-samples (See Table 2) exhibited agglomeration as defined in Section 2.0. 
Table 1 Summary of Sludge Samples of K Basins Sludge that have been collected

\begin{tabular}{|l|c|c|c|}
\hline \multicolumn{1}{|c|}{ Sampling Campaign } & $\begin{array}{c}\text { Year } \\
\text { Samples } \\
\text { Taken }\end{array}$ & $\begin{array}{c}\text { Number of } \\
\text { Samples }\end{array}$ & $\begin{array}{c}\text { Approximate } \\
\text { Volume of Sludge } \\
\text { Samples (liters) }\end{array}$ \\
\hline 1995- KE Floor and Weasel Pit & 1995 & 20 & 4 \\
\hline 1996 - KE Basin fuel canister & 1996 & 9 & 2.4 \\
\hline 1996 KW Basin fuel canister & 1996 & 8 & 0.1 \\
\hline $\begin{array}{l}\text { 1999 Core samples } \\
\text { Consolidated samples }\end{array}$ & 1999 & $11^{(\text {a) }}$ & 22 \\
\hline $\begin{array}{l}\text { 2003 One core sample KE NLOP } \\
\text { (a) }\end{array}$ & 2003 & 1 & 1.4 \\
\hline $\begin{array}{l}\text { 1993 Core samples from KE } \\
\text { NLOP } \\
\text { USQ sampling for criticality }\end{array}$ & 1993 & $13^{(\text {b) }}$ & N/A \\
\hline $\begin{array}{l}\text { 1998 Wash sludge components } \\
\text { (coatings \& internal sludge) } \\
\text { examined from fuel elements }\end{array}$ & 1998 & $9^{(\text {c) }}$ & N/A \\
\hline $\begin{array}{l}\text { 2009 Engineered Container } \\
\text { Sludge (KE Originating Sludge, } \\
\text { SCS-CON-240, -250 and -260) }\end{array}$ & 2009 & 6 & 5 \\
\hline $\begin{array}{l}\text { 2009 Engineered Container } \\
\text { Sludge (KW Originating Sludge, } \\
\text { SCS-CON-220) }\end{array}$ & 2009 & 5 & 1.4 \\
\hline $\begin{array}{l}\text { (a) These samples were prepared by combining sludge from multiple sampling locations } \\
\text { (b) } 1993 \text { samples from KE NLOP pit were consumed / disposed, and campaign is not considered useful with } \\
\text { respect to evaluation of agglomeration. } \\
\text { (c) Samples from this campaign were small and received at PNNL as dry material. }\end{array}$ \\
\hline
\end{tabular}


Table 2 Sludge Archive Samples for Compositing, Re-Jarring, Blending and Inventory ${ }^{5}$

\begin{tabular}{|c|c|c|c|}
\hline Sludge Sample & $\begin{array}{c}\text { Sludge } \\
\text { Sub-sample }\end{array}$ & Condition & $\begin{array}{l}\text { Approx. } \\
\text { Vol., ml }\end{array}$ \\
\hline \multirow[t]{8}{*}{ KC-2/3 Comp } & $\begin{array}{l}\text { KC-2/3 Settling } \\
\text { Study }\end{array}$ & Mushy, thick mud, black, no hardpan, with water & 100 \\
\hline & KC-2/3 Whole & $\begin{array}{l}\text { Stiff saturated mud, green, with water, easily dispersed } \\
\text { with water }\end{array}$ & 70 \\
\hline & $\mathrm{KC}-2 / 3 \mathrm{SS}$ & Very stiff, glass broken to collect sample, with water & 100 \\
\hline & KC-2 SSOL B & Very little solids with abundant water & 5 \\
\hline & $\begin{array}{l}\mathrm{KC}-3+ \\
\mathrm{KC}-2 \text { Rec } 2 \\
\end{array}$ & $\begin{array}{l}\text { Two jars with similar labels; solids wet but stuck to } \\
\text { bottom }\end{array}$ & 40 \\
\hline & $\mathrm{KC}-2 / 3 \mathrm{M} 250$ & $\begin{array}{l}\text { Hard chunks, very black, with water, easily dispersed with } \\
\text { water }\end{array}$ & 40 \\
\hline & $\mathrm{KC}-2 / 3 \mathrm{P} 250$ & Can be scooped out & 25 \\
\hline & $\mathrm{KC}-2 / 3 \mathrm{M} 250$ & $\begin{array}{l}\text { Very good with abundant water; source material for STP } \\
\text { Tests } 1 \text { and } 2\end{array}$ & $40-100$ \\
\hline \multirow[t]{5}{*}{ KC-4 Whole } & KC-4 & Abundant water & 50 \\
\hline & KC-4-L P6 & Sludge plug recovered, abundant water & $70-100$ \\
\hline & KC-4 Dup LPG & Well settled solids, with water & $30-50$ \\
\hline & $\mathrm{KC}-4$ & $\begin{array}{l}\text { Dry, but black, some retrieved as puck and some as } \\
\text { powder }\end{array}$ & $30-40$ \\
\hline & KC-4 Rec & Soft and readily suspendible & 40 \\
\hline \multirow[t]{2}{*}{ KC-6 } & KC-6 & Fully saturated, beads are clumped but readily break up & 100 \\
\hline & KC-6 SSOL A & Some clumping but fully wet & 125 \\
\hline \multirow[t]{2}{*}{ KE Floc Comp } & $\begin{array}{l}\text { KE Floc Sludge } \\
\text { (floc'd.) }\end{array}$ & Saturated, original plug fell apart with shaking & 200 \\
\hline & $\begin{array}{l}\text { KE Floc Comp } \\
\text { (not floc'd.) }\end{array}$ & $\begin{array}{l}\text { Saturated, original plug fell apart with shaking but not as } \\
\text { easily as flocculated sludge }\end{array}$ & 70 \\
\hline KC-1 M500 & KC-1 M500 & Stiff but readily sluiced, suspended, and re-settled & $50-70$ \\
\hline FE-5 Comp 1 & FE-5 Comp 1 & Reddish brown, can be penetrated and scooped & 200 \\
\hline KC-4-2 & $\mathrm{KC}-4 *$ & Dry chunks, water added and chunks broke up & 300 \\
\hline KC Floor Comp & KC Floor Comp & Wet, saturated, readily suspendible & $30-50$ \\
\hline KE Pit & KE Pit & Wet chunks, jar broken to recover & $150-200$ \\
\hline $96-01$ & $96-01$ & Very black solids & 15 \\
\hline $96-05$ & $96-05$ & Big chunks & 80 \\
\hline 96-13 KE Comp A & 96-13 KE Comp A & May contain some glass & 125 \\
\hline 96-08 SSOL & & Watered, dry before & 50 \\
\hline 96-15 SSOL & & Watered, dry before & 100 \\
\hline 96-09 SSOL & & None & 50 \\
\hline $96-11 \mathrm{SSOL}$ & & Very little sample & $<50$ \\
\hline 96-13 Settler Study & & Not watered, wet & 125 \\
\hline 96-13 Solid Grad & & Solids not watered, not wet & 100 \\
\hline 96-13 SSOL & & Not watered & 50 \\
\hline KE NLOP Jar \#1 & & Good, with water & 165 \\
\hline KE NLOP Jar \#2 & & Good, with water & 240 \\
\hline KE NLOP Jar \#3 & & Good, with water & 240 \\
\hline KC-6 carboy & & Good condition; 6-liter & 6400 \\
\hline KE Container Comp & & Moist, $70 \mathrm{ml}$ supernatant & 25 \\
\hline KE Container Comp Floc & & Moist, $30 \mathrm{ml}$ supernatant & 10 \\
\hline
\end{tabular}

\footnotetext{
${ }^{5}$ Table 1 courtesy of PNNL-17078 (53451-RPT01, 2007)
} 
Due to the relatively short time the $2009 \mathrm{KW}$ Engineered Container samples have spent in PNNL hot cell storage (i.e., conditions similar to those expected at T Plant), these samples were not considered in the determination of the frequency of sludge agglomeration.

It should be noted that the $>100$ sludge subsamples stored in the hot cells are visually inspected routinely at least twice a year and water is added as needed to prevent sample dry-out. However, unless required for testing, the samples are not disturbed or mixed. Therefore, it is unknown whether any of these undisturbed samples have consolidated into partially agglomerated forms over time. In addition, many samples collected from the $\mathrm{K}$ Basins never had enough time in storage to form agglomerates because they were either consumed in sample characterization testing or inadvertently dried out in the laboratory. With only 4 sludge samples or sub-samples forming agglomerates that impede the removal of sludge, these data provide a high level of optimism that most sludge materials stored for many years at conditions similar to those expected at $\mathrm{T}$ Plant can be readily re-suspended and mobilized.

\subsection{Conditions that Lead to the Formation of Agglomerates}

The data suggest that the formation of high strength agglomerates may have several key contributing factors. These factors include, but may not be limited to, total uranium content (i.e., sample homogeneity and influence of non-uranium compounds), uranium oxide composition (i.e., extent of conversion of tetravalent uraninite to hexavalent UOH compounds), sample dry-out, temperature, solubility, and storage time. Upon review of the available reports on $\mathrm{K}$ Basin sludge sampling and characterization, only samples $96-13, \mathrm{KC}-2 / 3 \mathrm{M} 250, \mathrm{KC}-2 / 3 \mathrm{SS}$, and $\mathrm{KE}$ Pit formed high strength agglomerates at conditions similar to those expected in $\mathrm{T}$ Plant. For the agglomerates of these four samples, only sample 96-13 was assessed for shear strength (estimated $15 \mathrm{kPa}$ to $65 \mathrm{kPa}$ ), as discussed later in Section 4.2 of this report.

Sample 96-13 has been estimated to have $\sim 2 \mathrm{wt} \%$ (dry) uranium metal and $\sim 82 \mathrm{wt} \%$ (dry) total uranium content. It was postulated that uranium metal content might be a common factor among samples that have formed high strength agglomerates. The uranium metal concentration is unlikely to be the underlying cause of the agglomeration observed in sample 96-13 since sample SNF Comp containing crushed fuel, floor sludge, and canister sludge did not show agglomeration and/or selfcementation. The uranium metal concentration of the SNF Comp sample (determined from two prior gas generation tests) was found to be $60 \%$ to $70 \%$ of the original $48.2 \mathrm{~g}$ of uranium metal present. Assuming no uranium metal reacted between the end of gas generation testing and the start of the compaction testing, there was a maximum of $28.9 \mathrm{~g}$ to $33.7 \mathrm{~g}$ of uranium metal present at the beginning of the compaction testing. This equates to $\sim 22.2 \mathrm{wt} \%$ (dry) uranium metal.

Another possible explanation for the presence of agglomeration in sample 96-13 and the absence of agglomeration in the SNF Comp sample is total uranium oxide content and the presence of hexavalent $\mathrm{UOH}$ compounds. As previously discussed, XRD analyses indicate the concentration of hexavalent UOH compounds metaschoepite and schoepite were relatively high in the agglomerated 96-13 sample when analyzed in 2007. In 1996, sample 96-13 was composed mainly of tetravalent uraninite compounds. The hexavalent $\mathrm{UOH}$ content in the KC-2/3 M250 sample was also relatively high and no tetravalent uraninite was observed in 2007 (PNNL-16496, Table 3.3), indicating that there is a link between the formation of agglomerates and the extent of conversion of tetravalent uraninite compounds to hexavalent UOH compounds when samples are stored under PNNL hot cell conditions. This 
conjecture is supported by XRD analysis performed in 1999, which showed sample 96-13 was high in tetravalent uraninite compounds and moderate in hexavalent UOH compounds (PNNL-13320, Table 2.7).

The SNF Comp sample, although relatively high in total uranium content ( $60.2 \mathrm{wt} \%$ dry), was not analyzed after the Compaction and Evaporation testing and therefore cannot be compared to samples $\mathrm{KC}-2 / 3 \mathrm{M} 250$ and 96-13 for the uranium compounds present. A probable reason sample SNF Comp did not undergo agglomeration is likely related to the extent of oxidation of the sample and the presence of non-uranium compounds. A significant portion of the sample is composed of non-hexavalent $\mathrm{UOH}$ compounds ( $39.8 \mathrm{wt} \%$-dry non-uranium constituents $+22.2 \mathrm{wt} \%$-dry $U$ metal) that may be interfering with the process of agglomeration. The presence of a significant concentration of uranium metal $(\sim 22$ wt\%-dry U metal) also indicates that a more reducing environment existed within the SNF Comp sample, which may have inhibited agglomeration further.

Homogeneity of the samples discussed may explain why some samples formed high strength agglomerates or self-cemented, and some did not. Agglomerates are more likely to form in sludge samples in which the majority of the uranium present is in the form of hexavalent UOH compounds. The presence of predominantly hexavalent $\mathrm{UOH}$ compounds in sludge may be predicted by the length of aging (storage), lack of gas generation, or shown through XRD results. For the KC-2/3 M250 sample, in which agglomeration occurred, the XRD results from 2007 indentified the predominant uranium compound as hexavalent metaschoepite (PNNL-16496, Table 3.3). Samples SNF Comp and KC-2/3 whole, which had relatively high total uranium content, may not have agglomerated due to the slightly lower total uranium content, lower level of homogeneity and less conversion of tetravalent uraninite to hexavalent $\mathrm{UOH}$ compounds. Therefore, samples with a higher degree of homogeneity in the uranium concentration present may form agglomerates of higher strength than samples of a more heterogeneous nature.

Temperature and solubility may also play a large role in the formation of agglomerates in $\mathrm{K}$ Basin sludge. The higher maximum temperatures of $\mathrm{T}$ Plant storage cells and the relatively oxic environment, compared to the chilled $\left(10^{\circ} \mathrm{C}\right.$ to $\left.15^{\circ} \mathrm{C}\right)$ anoxic $\mathrm{K}$ Basins, are expected to increase the rate of oxidation and formation of hexavalent $\mathrm{UOH}$ particles that are involved in the formation of agglomerates. Samples 96-13 and KC-2/3 M250 both experienced agglomeration at the hot cell ambient temperatures that typically range from $25^{\circ} \mathrm{C}$ to $35^{\circ} \mathrm{C}$. Sample $96-13$ showed evidence of oxidation via observed gas generation, which may also indicate that the sample was self-heating.

The solubility of the two main uranium phases believed to be involved in the oxidation reaction is shown in Figure 4. As the figure demonstrates, hexavalent metaschoepite, found in the agglomerated samples $96-13$ and $\mathrm{KC}-2 / 3 \mathrm{M} 250$, is several orders of magnitudes more soluble in water at $25^{\circ} \mathrm{C}$ and $\mathrm{pH}$ range of $\sim 6$ to 8 than tetravalent uraninite. This $\mathrm{pH}$ range is very similar to the $\mathrm{pH}$ range observed during the Compaction and Evaporation testing conducted with K Basin sludge samples (PNNL-15092, pg's $2.2-2.3$, Table 2.1 and Table 2.2 ). This range of $\mathrm{pH}$ is likely similar to what can be expected at $\mathrm{T}$ Plant during long-term storage in the STSCs and as supernatant water is added periodically. 
PRC-STP-00274, revision 1

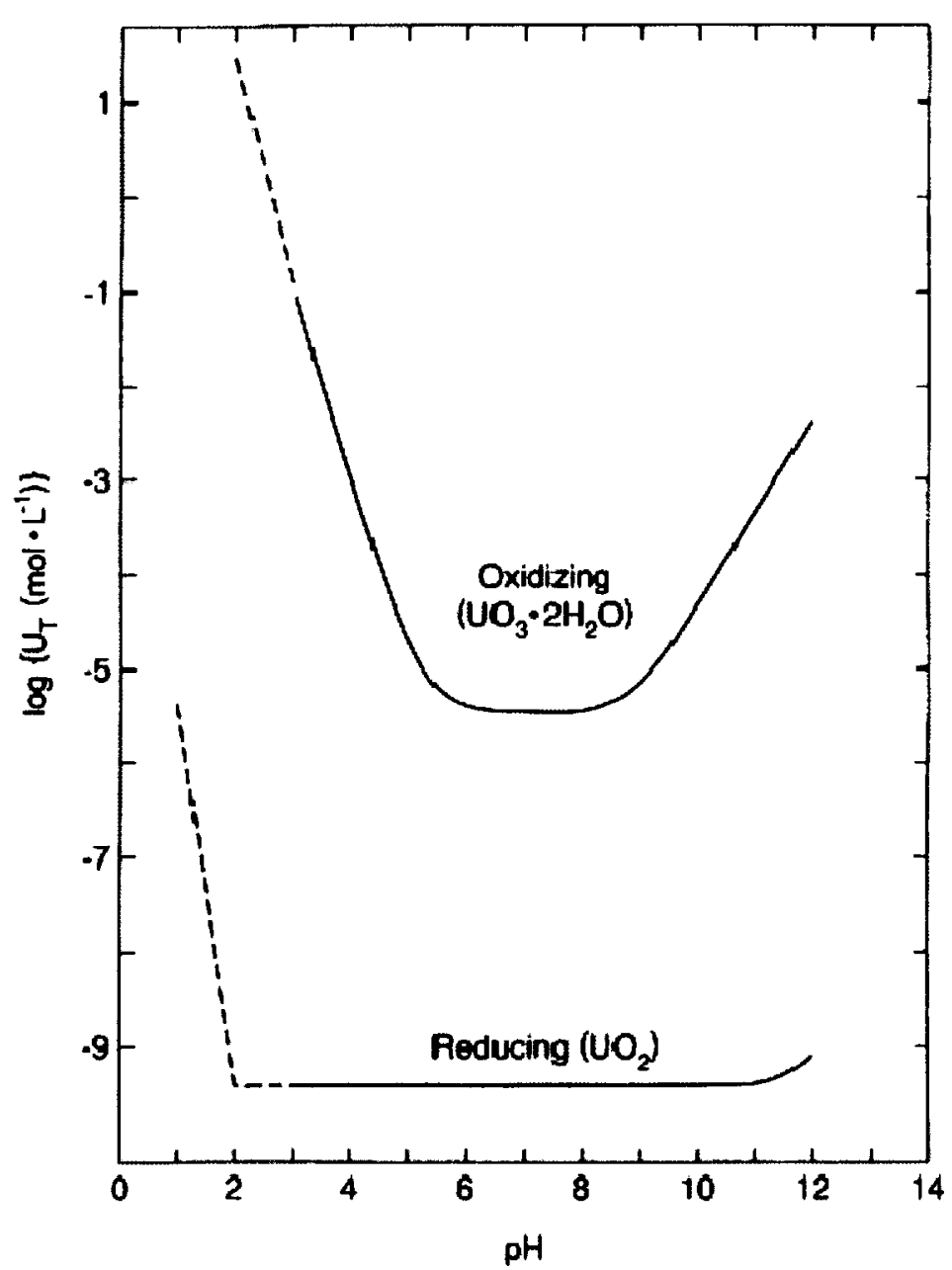

Figure 4 Solubility curve for U(IV) and U(VI) compounds ${ }^{6}$

It has been postulated that sample dry-out or loss of sludge cover water may also play a key role in agglomerate formation. This postulation mainly stems from the fact the sample 96-13 was discovered dry in the PNNL hot cell where it was stored $\sim 6$ months prior to the initiation of a 28 -month Compaction and Evaporation test. The sample was then wetted, mixed, and allowed to soak for 6 months prior to the test. It is unclear to what extent the physiochemical properties of the sludge were changed by this unintentional dry-out, but the sample subsequently formed high strength agglomerates and self cemented in its storage container sometime during the test even though a constant layer of cover water was kept over the sludge during the study (PNNL-15092). The KE Pit sample was prepared from dried KE Basin Weasel Pit samples that were re-wetted and exhibited agglomeration. Sample KC-2/3 M250 exhibited the formation of high strength agglomerates even while being stored under a constant layer of cover water in the PNNL hot cells. The KC-2/3 M250 sludge sample was discovered to have agglomerated when taken out of the hot cells for use in hydrothermal testing (PNNL-16496). Two additional samples, $\mathrm{KC}-2 / 3 \mathrm{SS}$ and $\mathrm{KE}$ Pit, both exhibited agglomerate formation while in PNNL hot

\footnotetext{
${ }^{6}$ Figure 4 courtesy of D.W. Shoesmith, 2000. Review, "Fuel corrosion processes under waste disposal conditions". Journal of Nuclear Materials 282 (2000) 1-31.
} 
cells and while being kept under a continuous layer of cover water. In 1996, all but one of the samples collected from the KE Basin Weasel Pit and Basin Floor experienced a complete loss of supernatant water. Once the samples lost their cover of water it was very difficult to reconstitute (wet/mix) back to their original condition (HNF-6705). It is also difficult to determine whether the chemical and physical properties were permanently altered due to the drying out. This event of all the KE Basin Weasel Pit and Basin Floor samples experiencing a loss of cover water may indicate that self-heating caused by radiolytic decay and/or oxidation of uranium metal present in the samples was ongoing, or simply evaporation due to sample storage conditions. Therefore, it is likely that sample dry-out contributes to the agglomeration of sludge, but is not necessarily required for agglomeration to occur.

Of the above-mentioned conditions that may lead to agglomerate formation, storage time may be the most influential. Four sludge samples archived in the PNNL hot cells have experienced agglomeration as of 2007. These samples are 96-13 (82.0 wt\%-dry Total U), KC-2/3 M250 (68.3 wt\%-dry Total U), KC-2/3 SS ( $\sim 59.0 \mathrm{wt} \%$-dry Total U) and KE Pit ( $~ 8 \mathrm{wt} \%$-dry Total U). All four samples except sample 96-13 were collected in 1999 and had been in PNNL hot cell storage for $\sim 8$ years when each was discovered to have formed high strength agglomerates. Sample 96-13 was in storage from 1996 to 2002 ( $\sim 6$ years) before it was found to have dried out and then formed high strength agglomerates in subsequent compaction and evaporation testing. Storage time may be a major factor contributing to agglomerate formation for KE Engineered Container sludge, KW Engineered Container sludge, and Settler sludge because these sludge types may be stored in the STSCs for at least 10 years at T Plant.

\subsection{Postulated Physical and Chemical Mechanisms of Agglomerate Formation}

Testing performed by PNNL demonstrates that certain sludge types can form high strength agglomerates (i.e., "hardpan") ${ }^{7}$. In some cases, hardpan layers formed at the bottom of test vessels and in other instances they formed at the air-water interface as a floating crust. The formation of $\mathrm{K}$ Basin sludge agglomerates is likely related to the oxidation of uranium metal to higher oxidation states in watersaturated environments. Uranium metal is known to oxidize to uranium (IV) oxidation state via the following chemical reaction (equation 1). The rate of metal oxidation (as a linear penetration) is given by equation 2 and is valid for anoxic conditions over a temperature range of $24^{\circ} \mathrm{C}$ to $350^{\circ} \mathrm{C}$ (HNF-SDSNF-TI-015, Vol 2, Rev 14A, Table 4.9).

$$
\begin{aligned}
& U_{\text {Metal }}+2 \mathrm{H}_{2} \mathrm{O} \stackrel{\text { yields }}{\longrightarrow} \mathrm{UO}_{2}+2 \mathrm{H}_{2} \\
& \log _{10} R_{C}=9.975-3365 / T(K)[\mu m / h]
\end{aligned}
$$

\footnotetext{
${ }^{7}$ March 2010 Monthly Status Report For PNNL Contracts Providing Technical Support to K Basin Closure and Sludge Treatment Projects, Pacific Northwest National Laboratory, Richland WA.
} 
Further oxidation of uranium (IV) oxides to uranium (VI) oxides (i.e., schoepite and metaschoepite) can be expected if the dissolved oxygen concentration is sufficiently high, which is likely to be the case when sludge is stored in STSCs at T Plant due to the vented container design. These hexavalent uranyl oxide hydrate $(\mathrm{UOH})$ compounds will likely form at the air-water interface, or depending on the crystal structure and level of hydrophobicity, at the bottom of the vessel at the sludge-water interface. The depth of oxygen penetration into the sludge bed will likely have a strong influence on the formation of UOH compounds in the STSCs. The diffusion rate of oxygen into a stationary sludge bed has been previously investigated (PNNL-14228, Appendix A) and the oxidation of uranium will likely be diffusion limited.

Previous works for uranium oxide fuel disposal in a geologic repository demonstrate that metaschoepite, an oxidation product of uraninite $\left(\mathrm{UO}_{2}\right)$, preferentially forms fractal aggregates at air-water interfaces (PNNL-14306). These fractal aggregates surprisingly float even though their densities are much greater than that of water. This anomalous behavior of heavy metal oxides floating at the surface of water-filled containers has been observed in several different colloid compounds including uranyl oxide hydrates, tungsten oxide, thorium oxide, plutonium oxide. It is postulated that this floating phenomena is due to the level of hydrophobicity and the orientation of surface charge in the crystal structure of metaschoepite (PNNL-14306). Similar instances of floating heavy metal oxide solids have occurred during laboratory testing of uraninite oxidation at $\mathrm{PNNL}^{8}$. These floating layers of agglomerates however have no perceptible strength. The shear strength of the UOH compounds formed during uraninite oxidation is discussed further in Section 4.1.

Figure 5, Figure 6 and Figure 7 (below) pictorially demonstrate these phenomena in progress. Figure 5 shows three particles of uraninite roughly $40 \mu \mathrm{m}$ in diameter undergoing oxidation and forming UOH fractal aggregates of small particles consisting of primarily metaschoepite and small pieces of uraninite. Figure 6 is magnified image of the uraninite oxidation process, and shows particles of uraninite (dark) roughly $0.1 \mu \mathrm{m}$ to $0.150 \mu \mathrm{m}$ in diameter producing particles of metaschoepite (light) roughly $0.05 \mu \mathrm{m}$, as seen in detail in Figure 7.

\footnotetext{
${ }^{8}$ Delegard, C. H., 2009. Preliminary Status: Uraninite Aqueous Oxidation by Oxygen Gas at $50^{\circ} \mathrm{C}$
} 


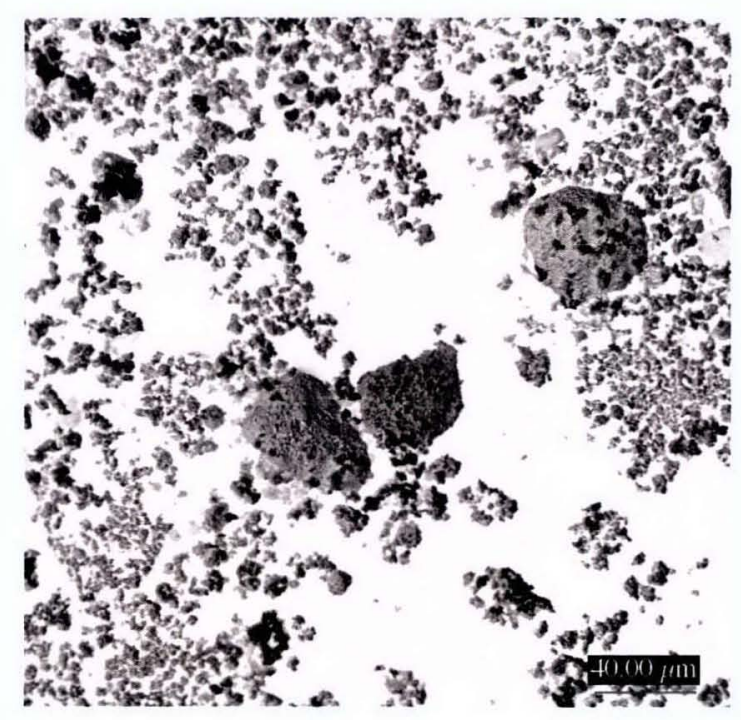

Figure 5 Electron Micrograph of Agglomeration Process

Inverted Contrast Backscattered Electron Scanning Electron Micrograph of Micro- Crystals of Meta-Schoepite with Smaller Fragments of UO2 Formed During Corrosion of Uranium Oxide. ${ }^{9}$

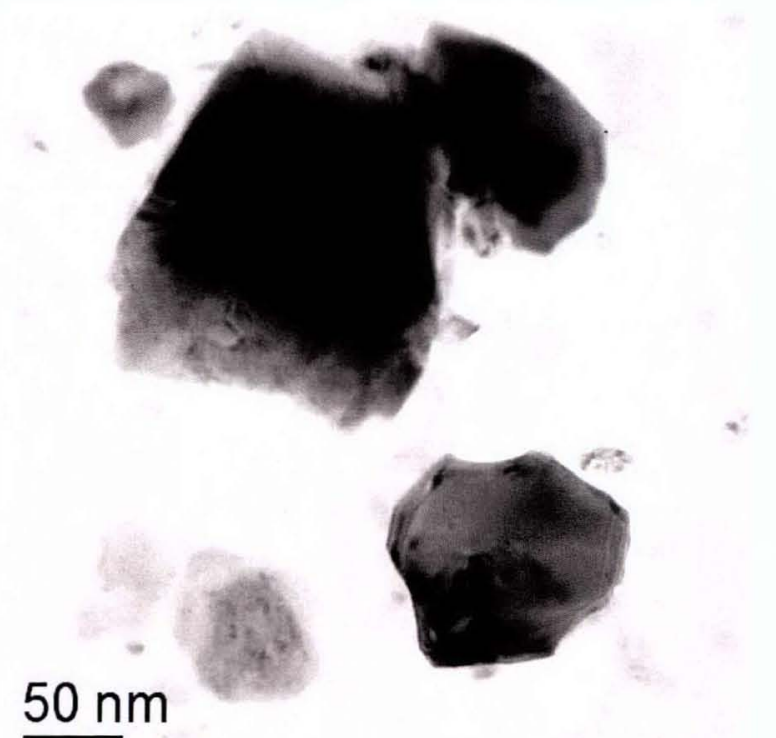

Figure 6 TEM image of Metaschoepite Formation

Figure shows the process of colloidal uranyl oxide hydrates forming from corrosion of uraninite particles. ${ }^{10}$

\footnotetext{
${ }^{9}$ Figure courtesy of PNNL-14306, pg 5.3

${ }^{10}$ Figure courtesy of PNNL-14306, pg 5.4
} 
The images in Figure 7 are a magnification of the fractal aggregates formed at the air-water interface. The small roughly $0.05 \mu \mathrm{m}$ particles of metaschoepite coalesce and form sheets with fractal geometry as seen in both images below. The image on the right also indicates the presence of partially corroded uraninite pieces roughly $5 \mu \mathrm{m}$ in diameter and black in color.
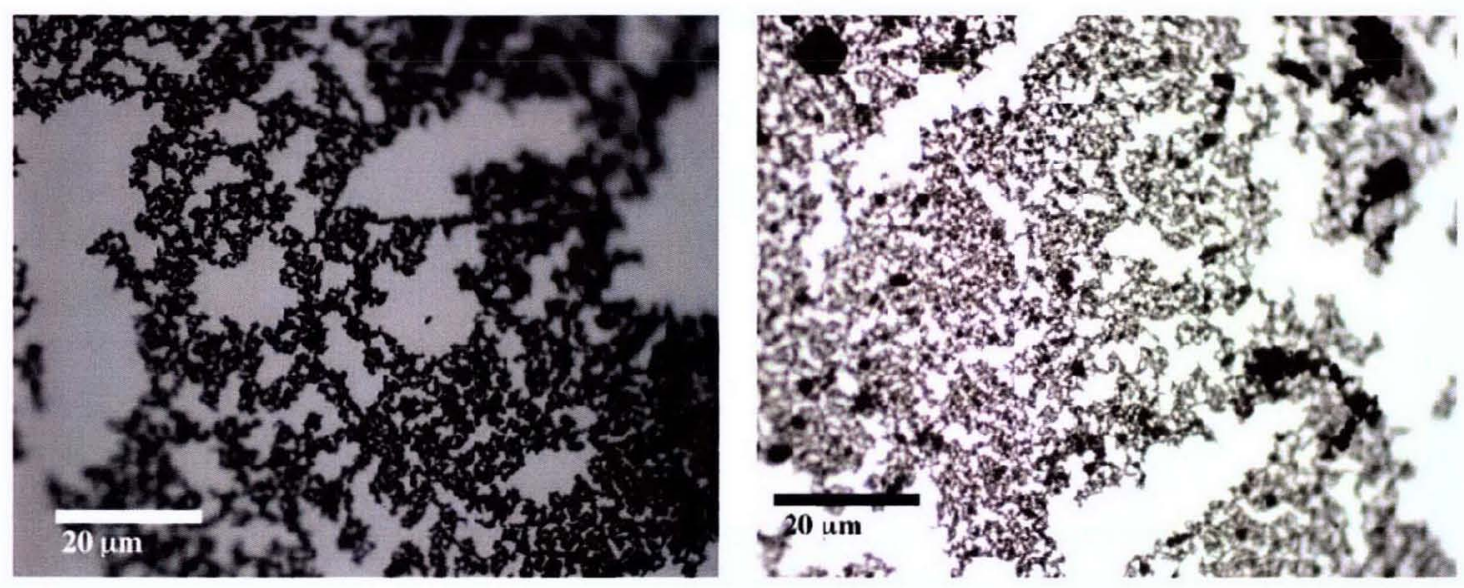

Figure 7 Agglomeration of $\mathrm{UOH}$ fractal aggregates at the air-water interface. ${ }^{11}$

The exact mechanism of agglomerate formation among $\mathrm{K}$ Basin sludge is not known. The mechanism is likely a combination of many chemical and physical events that result in the formation of high strength agglomerates and the self-cementation of sludge as seen in samples 96-13, KC-2/3 M250, KC-2/3 SS and KE Pit. Of the possible mechanisms of agglomerate formation, Ostwald ripening could be a possible underlying mechanism of agglomerate formation. Ostwald ripening is defined as the growth of smaller precipitating particles to form larger agglomerates with the same chemical composition. Rhythmic precipitation mechanisms are also likely to be involved in agglomerate formation, as alternating bands of yellow and green $\mathrm{UOH}$ solids have been seen during uraninite oxidation testing ${ }^{12}$. This layering effect is sometimes referred to as "Liesegang Banding" or "Liesegang Rings".

Even though multiple mechanisms may be involved in the formation of large high strength agglomerates, several similarities between the KE Basin sludge samples 96-13, KC-2/3 M250, KC-2/3 $\mathrm{SS}$, and KE Pit are immediately apparent. All four samples formed agglomerates at relatively moderate temperatures, comparable to the maximum temperature that can be expected in STSCs during storage at T Plant. XRD analyses show medium to high concentrations of metaschoepite and schoepite for samples 96-13 and KC-2/3 M250, which indicate a high degree of uraninite conversion to hexavalent $\mathrm{UOH}$ compounds. Unfortunately, XRD analyses could not be located for sample $\mathrm{KC}-2 / 3 \mathrm{SS}$ and no crystalline uranium phases were detected in sample KE Pit. Samples 96-13, KC-2/3 M250 and KC-2/3 SS were all relatively high in total uranium content with a high degree of sample homogeneity. Lastly,

\footnotetext{
${ }^{11}$ Figure courtesy of PNNL-14306, pg 5.2

${ }^{12}$ Delegard, et al., 2009. Preliminary Status: Uraninite Aqueous Oxidation by Oxygen Gas at $50^{\circ} \mathrm{C}$, Pacific Northwest National Laboratory, Richland WA.
} 
all four of the samples were placed in PNNL hot cell storage for a period of 6 years to 8 years before being inspected indicating a correlation between storage time and agglomeration.

The extent of oxidation of the tetravalent uranium compounds to hexavalent UOH compounds is likely related to another important physical parameter, particle size. Since particles of relatively small diameter have a higher surface area to volume ratio, it is likely that the smaller diameter fraction of sludge is oxidizing more quickly than the larger diameter fraction. Although no particle size distribution data could be located for samples $96-13, \mathrm{KC}-2 / 3 \mathrm{SS}$ and KE Pit, the PSD for sample KC-2/3 M250 is roughly $250 \mu \mathrm{m}$ or less.

It is also possible that the removal of sludge from the anoxic environment of the basin is playing a key role in the extent of hexavalent $\mathrm{UOH}$ formation. The oxidation of sludge during storage in PNNL hot cells may proceed faster toward equilibrium products (UOH compounds) even if the samples are kept wet, due to the higher temperature $\left(25^{\circ} \mathrm{C}\right.$ to $\left.35^{\circ} \mathrm{C}\right)$ as compared to the water of the $\mathrm{K}$ Basin $\left(10^{\circ} \mathrm{C}\right.$ to $15^{\circ} \mathrm{C}$ ), and a more oxic environment. The rate of conversion of uraninite to metaschoepite at $21^{\circ} \mathrm{C}$ and $50^{\circ} \mathrm{C}$ via the reaction with dissolved oxygen in water has been established in PNNL-17678. Ultra pure oxygen gas was bubbled through the uraninite samples to convert the uraninite to metaschoepite. The mean starting diameter for the uraninite particles was $6 \mathrm{~nm}$ with agglomerates up to $600 \mathrm{~nm}$ (PNNL17678, page 4.19). At $21^{\circ} \mathrm{C}$, over $95 \%$ of the uraninite was oxidized to pure metaschoepite after 25 days. Since, the study described in PNNL-17678 used a stirred reaction vessel the conversion of uraninite occurred much faster than would be expected for $\mathrm{K}$ Basin sludge stored in the static environment of the STSC. This study however does provide the STP with a bounding case for the amount of uraninite converted (i.e., maximum extent of reaction possible in the STSC). Figure 8 below illustrates the increase in the rate of reaction with temperature for shrinking core kinetics in a stirred reaction vessel in terms of reaction progress.

The combination of this change in environment (elevated temperature and increased dissolved oxygen content), the relatively high total uranium content (i.e., high sample homogeneity) among three of the four samples examined, the high prevalence of hexavalent metaschoepite in samples $96-13$ and $\mathrm{KC}-2 / 3$ M250, and the relatively long storage periods in PNNL hot cells for all samples examined are all likely contributing factors in the formation of agglomerates. The agglomeration of KE Engineered Container sludge and KW Engineered Container sludge is less likely to occur due to the relatively low total uranium content compared to the sludge samples that have formed high strength agglomerates.

Recent KW Engineered Container (EC) sludge sampling and characterization indicates that the presence of constituents other than uranium oxides in $\mathrm{K}$ Basin sludge may actually inhibit agglomerate or "hardpan" formation (PNNL-19035). Samples were obtained from the KW Basin floor and canister sludge stored in KW Engineered Container SCS-CON-220 and KE Basin floor and canister sludge stored in KW Engineered Containers SCS-CON-240, -250, and -260. The following figure is a proposed illustration of this agglomeration inhibition effect. As Figure 9 illustrates, the formation of large agglomerates that could be detrimental to the removal of sludge after the prescribed interim storage at $\mathrm{T}$ Plant are physically inhibited by the presence of other particles in the sludge such as hydroxides of iron and aluminum. 


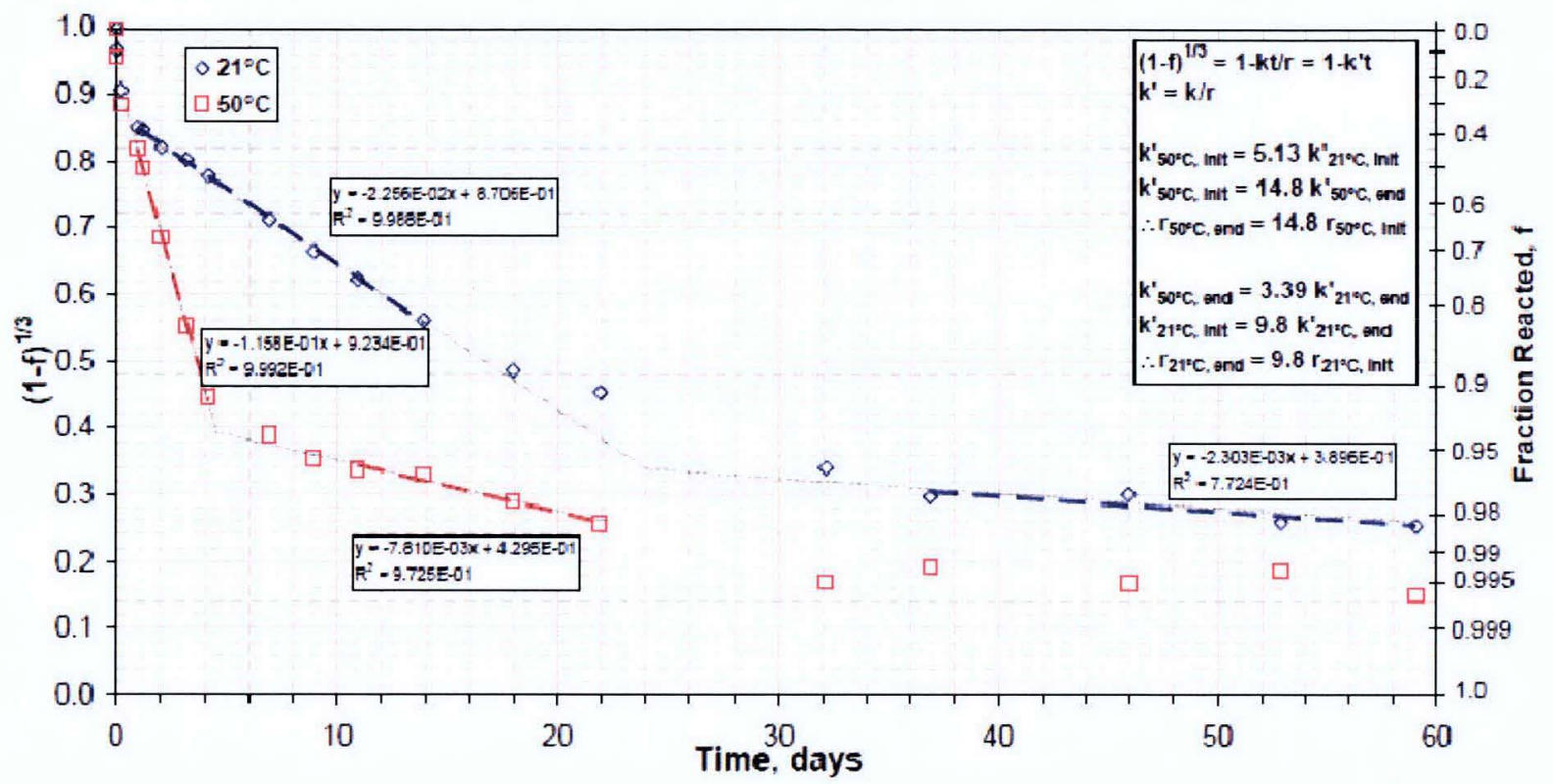

Figure 8 Shrinking Core Kinetics for uraninite oxidation

Plot of the rate of uraninite oxidation at $21^{\circ} \mathrm{C}$ and $50^{\circ} \mathrm{C}$ in a stirred reaction vessel $(\mathrm{f}=0$ indicates no oxidation has occurred or pure uraninite, and $\mathrm{f}=1$ indicates oxidation of uraninite has gone to completion or pure metaschoepite). ${ }^{13}$
Large agglomerate
Many micro-agglomerates

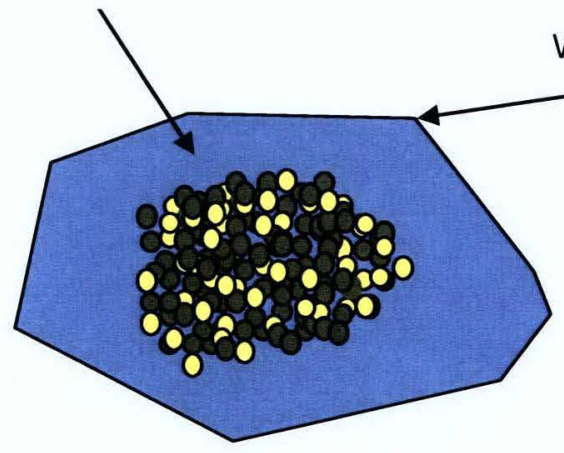

(a) Agglomerate of $\mathrm{UO}_{3}$ particles: Olive green indicates schoepite and yellow indicates metaschoepite.

Water Matrix

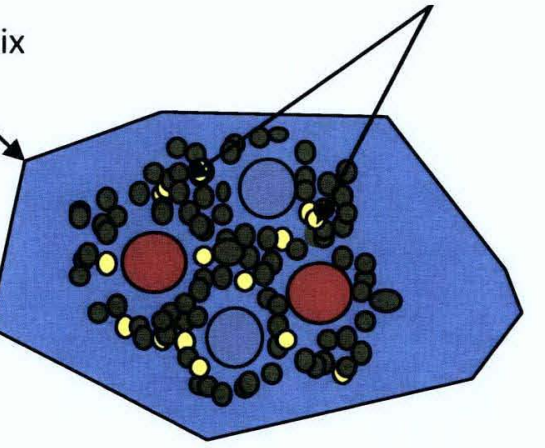

(b) The formation of micro-agglomerates inhibiting formation of larger agglomerates due to interference with non-uranium particles such as iron and aluminum hydroxides.

Figure 9 Illustration of Agglomerates Formation

(a) Illustration of agglomeration formation via coalescence of uranium (VI) oxide particles

(b) Illustrates the inhibition effect of agglomeration when other constituents are present

\footnotetext{
${ }^{13}$ Figure courtesy of PNNL-17678, pg 4.21
} 
Sampling and characterization show that sludge from KW Engineered Containers SCS-CON-220, -240, -250 , and -260 have much lower total uranium content than sample $96-13, \mathrm{KC}-2 / 3 \mathrm{M} 250$ and $\mathrm{KC}-2 / 3 \mathrm{SS}$ (PNNL-19035 and PRC-STP-00212). Table 3 and Table 4 shows the total uranium content of the sludge currently stored in Engineered Containers SCS-CON-220, -240, -250, and -260. The data was collected from core sampling campaigns in the summer of 2009, and yield spatial information on the distribution of uranium compounds in the Engineered Containers. The highest total uranium concentration, $35.2 \mathrm{wt} \%$ (dry) was measured in core sample B1 from KW Engineered Container SCSCON-220. This concentration is well below the level seen in three of the four samples (i.e. $59.0 \mathrm{wt} \%$, $68.3 \mathrm{wt} \%$ and $82 \mathrm{wt} \%$ dry) that formed agglomerates and indicates that the sludge is heterogeneous in nature.

Table $3 \mathrm{KW}$ Engineered Container sludge dry weight \% total uranium

\begin{tabular}{|c|c|c|c|c|}
\hline & \multicolumn{4}{|c|}{ SCS-CON-220 } \\
\hline Core & A1 & B3 & A3 & B1 \\
\hline${\text { U wt } \% \text { (total-dry) }^{14}}^{22.7}$ & 19.3 & 24.9 & 35.2 \\
& 23.2 & 20.2 & 17.6 & 34.0 \\
\hline
\end{tabular}

Table 4 KE Engineered Container sludge dry weight \% total uranium

\begin{tabular}{|c|c|c|c|c|c|}
\hline & \multicolumn{2}{|c|}{ SCS-CON-240 } & SCS-CON-250 & \multicolumn{2}{|c|}{ SCS-CON-260 } \\
\hline Core & A2 & B1 & B2 & A1 & B3 \\
\hline U wt\% (total-dry) ${ }^{14}$ & 5.37 & 4.65 & 5.39 & 6.00 & 6.10 \\
& & & & & 6.23 \\
\hline
\end{tabular}

Preliminary results of uraninite oxidation testing currently being performed at PNNL using a uraniumcontaining KW sludge simulant demonstrate that sludge with a more heterogeneous nature does not form agglomerates of significant strength ${ }^{15}$. Figure 10 shows three $\mathrm{KW}$ sludge simulant samples being aged at $50^{\circ} \mathrm{C}$. The sample on the left is the experimental control with no exposure to ultra pure oxygen (99.99\%), while the samples in the middle and on the right have been exposed to 42 days of ultra pure oxygen ( $99.99 \%$ purity) and 70 days of ultra pure oxygen (99.99\% purity), respectively. Preliminary inspection of all three samples indicates that the sludge has no perceptible shear strength as indicated by the top layer of solids slumping as the graduated cylinders are tilted. This preliminary result agrees well with the hypothesis that sludge of a more heterogeneous nature (with respect to uranium constituents) is less likely to form agglomerates.

\footnotetext{
${ }^{14}$ Some of the core samples had multiple readings for total uranium content and speciation data as reported in PNNL-19035.

${ }^{15}$ May 2010 Monthly Status Report For PNNL Contracts Providing Technical Support to K Basin Closure and Sludge Treatment Projects, Pacific Northwest National Laboratory, Richland WA.
} 

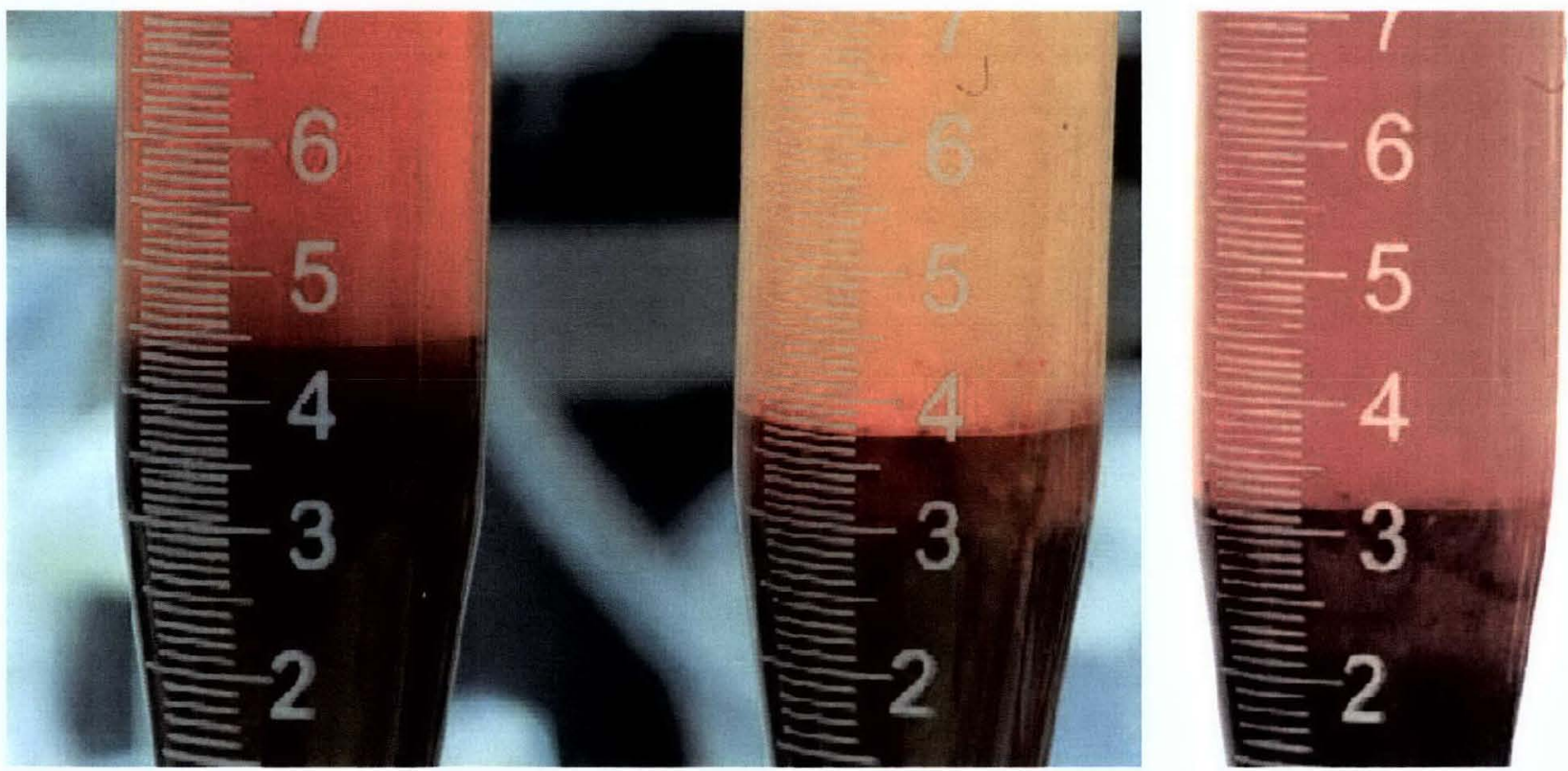

Figure 10 PNNL $\mathrm{UO}_{2}$ oxidation test

Test tube on left is control sludge sample $\left(50^{\circ} \mathrm{C}\right.$, no $\left.\mathrm{O}_{2}\right)$, middle $\left(50^{\circ} \mathrm{C}, 42\right.$ days of $\left.\mathrm{O}_{2}\right)$, right $\left(50{ }^{\circ} \mathrm{C}, 70\right.$ days of $\left.\mathrm{O}_{2}\right)$

Further validity is given to the idea that the KE Engineered Container sludge and KW Engineered Container sludge will not form agglomerates when stored in static water filled STSCs in T Plant when the contents of Engineered Container SCS-CON-220 are studied further. As discussed in Section 4.1, mixtures of uranium oxides that have roughly $50 \% \mathrm{UO}_{2}$ and $50 \% \mathrm{UO}_{3}$ in a pure uranium oxide system have demonstrated the formation of uncharacteristically high shear strength agglomerates or "hardpans". The approximately 50:50 ratios of $\mathrm{UO}_{2}$ to $\mathrm{UO}_{3}$ has been observed in recent samples taken from $\mathrm{KW}$ Engineered Container SCS-CON-220 as seen in Table 5, however no agglomeration has been observed. This may be because the SCS-CON-220 sample is not a pure uranium oxide system as the sample discussed in Section 4.1. The highest total uranium content observed in a SCS-SON-220 sample is 35.2 $w t \%$ (dry). The remaining constituents of the sludge may hinder the formation of large, high shear strength agglomerates as discussed previously and shown in Figure 9.

Table 5 Uranium Speciation Data by Engineered Container Core Composite Sieve Fraction

\begin{tabular}{|c|c|c|c|c|c|c|c|c|c|}
\hline $\begin{array}{c}\text { Engineered } \\
\text { Container }\end{array}$ & \multicolumn{3}{|c|}{ SCS-CON-220 } & \multicolumn{2}{c|}{ SCS-CON-240 } & \multicolumn{2}{c|}{ SCS-CON-250 } & \multicolumn{2}{c|}{ SCS-CON-260 } \\
\hline Sieve Fraction $^{16}$ & LCC & MCC & SCC & MCC & SCC & MCC & SCC & MCC & SCC \\
\hline U (IV) & & & & & & & & & \\
\hline & $>56.1$ & 50.3 & 47.9 & 36.9 & $>92.9$ & $>72.0$ & $>88.1$ & $>80.8$ & 67.8 \\
& & 53.7 & 49.0 & & & & & $>82.4$ & 63.8 \\
\hline U (VI) & $>43.9$ & 49.7 & 52.1 & 63.1 & $<7.1$ & $<28.0$ & $<11.9$ & $<19.2$ & 32.2 \\
& & 46.3 & 51.0 & & & & & $<17.6$ & 36.2 \\
\hline
\end{tabular}

\footnotetext{
${ }^{16} \mathrm{LCC}$ is the sieve fraction with particle size greater than $2,000 \mu \mathrm{m}$. MCC is the sieve fraction with particle size greater than $500 \mu \mathrm{m}$ but less than $2,000 \mu \mathrm{m}$. SCC is the sieve fraction with particle size less than $500 \mu \mathrm{m}$.
} 
The following figure shows the correlation of total uranium content (dry wt $\%$ basis) with agglomerate formation among 14 samples collected from 1996 to 2009. Since the samples collected in 2009 have only had a limited period of time to age in the PNNL hot cells, the data associated with agglomerate or "hard pan" formation is somewhat limited. The four samples (96-13, KC-2/3 M250, KC-2/3 SS, and KE Pit) that exhibited agglomeration while stored in the PNNL hot cells are depicted as orange triangles in Figure 11. With the exception of the KE Pit sample, sludge samples with less than 59 wt $\%$ total uranium were not observed to form agglomerates. The KE Pit sample was prepared from other KE Basin Weasel Pit samples that were dried and re-wetted, which could explain why this sample formed agglomerates even though the total uranium content was only $8 \mathrm{wt} \%$ (dry).

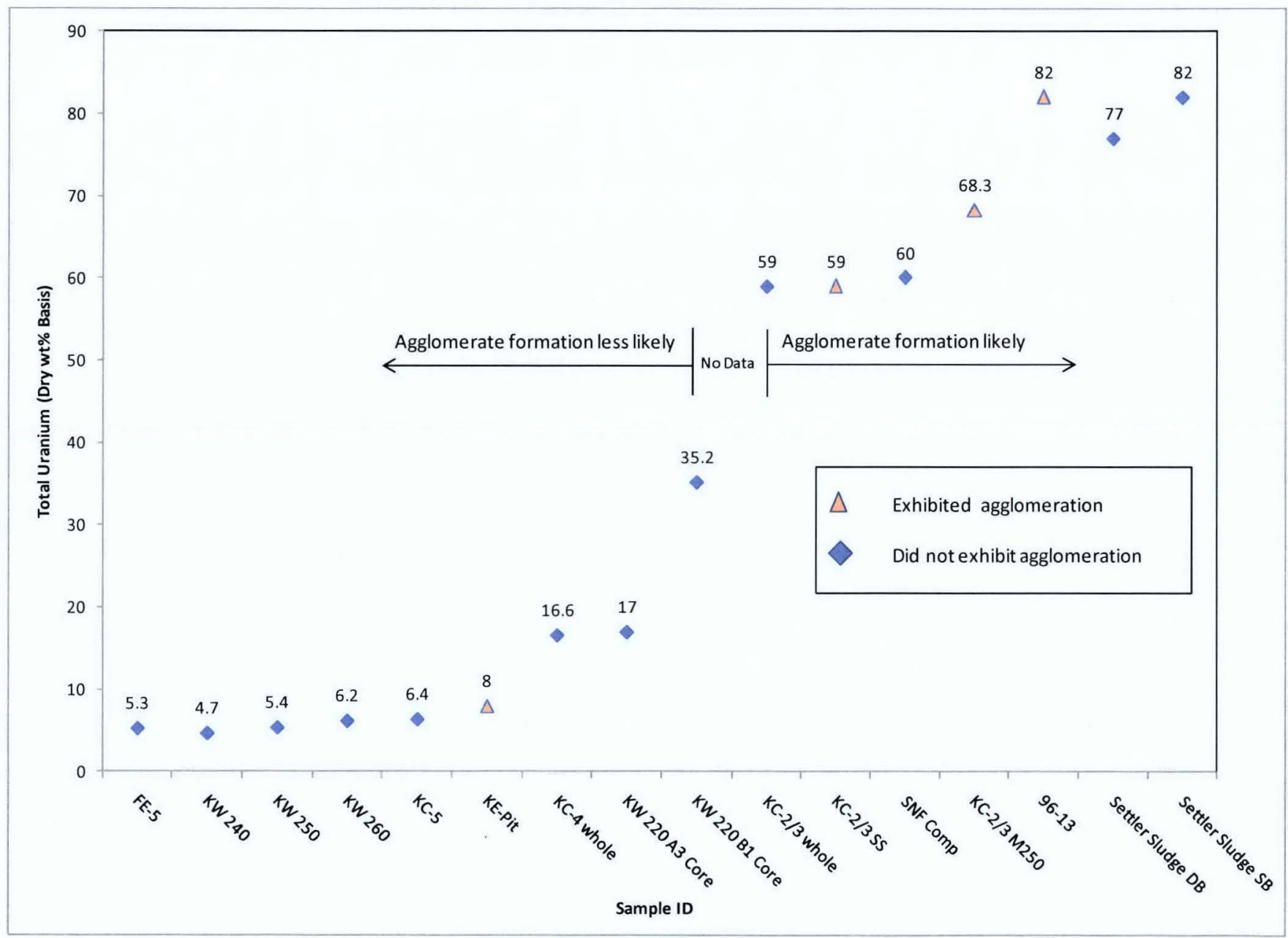

Figure 11 Correlation of total uranium (dry basis)

Figure 11 shows the correlation of agglomerate formation with total uranium for 16 samples of KE and KW Basin sludge.

While the formation of agglomerates is undoubtedly a complex mechanism that is yet to be fully understood, the extent of conversion of U(IV) compounds to U(VI) compounds, the total uranium content (i.e., sample homogeneity) of the sludge and storage time are believed to be the main contributing factors. Since only 4 sludge samples and sub-samples taken from the K Basins have been 
identified to form agglomerates, the available quantitative data is insufficient to determine the weight of each of these postulated factors.

To summarize, the mechanism of agglomerate formation involves several steps and prerequisite conditions. First, the sludge must contain a high level of total uranium oxides that can react with dissolved oxygen in water to yield UOH compounds (e.g., metaschoepite and schoepite). These small oxidation products then spall off the larger uranium oxide pieces and coalesce to form fractal aggregates of $\mathrm{UOH}$ particles. This process is expedited in environments with higher temperatures and a ready supply of oxygen, which is similar to the conditions in the PNNL hot cells or T Plant. These networks of UOH particles subsequently congregate and form larger agglomerates. In order for large high strength agglomerates to form, the sample homogeneity must be relatively high, as in samples $96-13$ (82 dry wt\% total U), KC-2/3 M250 (68.3 dry wt\% total U) and KC-2/3 SS ( 59.0 dry wt\% total U). Due to the relatively low total uranium content in the core samples collected from the KW Engineered Containers, the formation of rigid high shear strength agglomerates is not expected to occur.

There is the possibility of localized pockets of sludge high in uranium concentrations that could meet all the prerequisites for the formation of high shear strength agglomerates inside the STSCs. Modeling has been conducted to estimate the distribution of sludge components after retrieval from an engineered container and settling in a STSC (PRC-STP-00162 and PRC-STP-00220). Each batch of sludge retrieved into a STSC is predicted to settle into a bottom layer containing all of the uranium metal and some of the uranium oxides with a top layer containing the remaining uranium oxides and the nonuranium oxides. Therefore, it is possible for localized high total uranium concentrations to exist in a STSC.

Additionally, the Settler Tank sludge, which has been retrieved into KW Engineered Container SCSCON-230, is estimated to contain $77 \mathrm{wt} \%$ to $82 \mathrm{wt} \%$ (dry) total uranium. The Settler Tank sludge is likely to be more susceptible to agglomerate formation than the KE Engineered Container sludge or KW Engineered Container sludge due to the higher total uranium content and smaller particle size $(<600$ $\mu \mathrm{m}$ ), which is similar to the total uranium content of the 96-13 sample. Characterization activities planned for FY 2011 will provide the STP with total uranium concentration and uranium speciation data for the Settler Sludge material. This data will be incorporated into this report as it becomes available.

Ongoing testing ${ }^{17}$ at PNNL may provide additional insight on the mechanisms responsible for agglomerate formation. The testing is utilizing settled uraninite solids and an uranium containing $\mathrm{KW}$ sludge simulant that are subjected to oxidation via a steady flow of ultra-pure $(99.99 \%)$ oxygen at $50^{\circ} \mathrm{C}$.

\footnotetext{
${ }^{17}$ May 2010 Monthly Status Report For PNNL Contracts Providing Technical Support to K Basin Closure and Sludge Treatment Projects, Pacific Northwest National Laboratory, Richland WA.
} 


\subsection{Agglomerated Sludge Mobilization}

If agglomeration is suspected to occur during storage at T Plant, the STP needs to know the relative shear strengths of such material for the design of a mobilization and retrieval tool. The following sections discuss the effect of the conversion of tetravalent uranium (IV) compounds (i.e., uraninites) to hexavalent uranium (VI) compounds (i.e., UOHs) has on the shear strength of a $100 \%$ uranium oxide system. In addition to the pure uranium oxide system discussed in section 4.1 , real $\mathrm{K}$ Basin agglomerated sludge sample 96-13 was evaluated for shear strength and the results are discussed in Section 4.2.

\subsection{Shear Strength of Varying U Oxide Mixtures}

Testing performed by PNNL in February $2010^{18}$ show that mixtures of uranium oxides with varying tetravalent uranium and hexavalent uranium (i.e. $\mathrm{UO}_{2}: \mathrm{UO}_{3} \cdot 2 \mathrm{H}_{2} \mathrm{O}$ ) ratios differ significantly in the shear strength or yield stress. Samples of tetravalent uraninite in water were oxidized by bubbling ultra pure oxygen into the water at room temperature. Three samples with uranium oxide compositions $100 \% \mathrm{UO}_{2}$ (sample 1), $49 \% \mathrm{UO}_{2}: 51 \% \mathrm{UO}_{3} \cdot 2 \mathrm{H}_{2} \mathrm{O}$ (sample 2), and $35 \% \mathrm{UO}_{2}: 65 \% \mathrm{UO}_{3} \cdot 2 \mathrm{H}_{2} \mathrm{O}$ (sample 3) were transferred to $120 \mathrm{ml}$ jars and allowed to settle undisturbed for a period of $3 \frac{1}{2}$ months. After the settling periods, the undisturbed shear strength were determined to be $350 \mathrm{~Pa}$ to $430 \mathrm{~Pa}$, greater than $27,000 \mathrm{~Pa}$ (rheometer maximum torque exceeded), and $80 \mathrm{~Pa}$ to $100 \mathrm{~Pa}$ for samples 1,2 , and 3, respectively.

In the process of removing the shear vane from sample $2\left(49 \% \mathrm{UO}_{2}: 51 \% \mathrm{UO}_{3} \cdot 2 \mathrm{H}_{2} \mathrm{O}\right)$, the material was partially mixed. This provided PNNL the opportunity for a partially mixed shear measurement. In order to take an intermediate measurement on sample 2, the sample was allowed to settle for $72+$ hours after the partial mixing. After the $72+$ hour settling time, sample 2 was determined to have shear strength of $3,800 \mathrm{~Pa}$ to $16,000 \mathrm{~Pa}$, which is significant. All three samples were then mixed aggressively and allowed to settle for $72+$ hours. Samples 1,2 , and 3 were determined to have shear strengths of $140 \mathrm{~Pa}$ to $190 \mathrm{~Pa}, 980 \mathrm{~Pa}$ to $1,700 \mathrm{~Pa}$, and $45 \mathrm{~Pa}$ to $53 \mathrm{~Pa}$, respectively.

To determine if the sample shear strength rebuilds after aggressive mixing, an additional shear strength measurement was collected in March 2010 following 5 weeks of undisturbed settling ${ }^{19}$. Prior to the 5 week settling period, all three samples were manually mixed with a metal spatula for $\sim 5$ minutes. The $49 \% \mathrm{UO}_{2}: 51 \% \mathrm{UO}_{3} \cdot 2 \mathrm{H}_{2} \mathrm{O}$ mixture could not be completely homogenized with the spatula, and after mixing, the sample was lumpy with well-mixed portions. A layer of water was added to the top of the container to minimize water loss during the settling period inside the fume hood. Unfortunately, the container was not airtight and evaporation of the overlying water occurred. The top of the sample formed a very thin 'skin' and a small fracture down the center of the sample was observed. The shear strength observed for the $49 \% \mathrm{UO}_{2}: 51 \% \mathrm{UO}_{3} \cdot 2 \mathrm{H}_{2} \mathrm{O}$ mixture was slightly higher than the values obtained at $72 \mathrm{hr}$ settling time. Water was observed seeping out of the sample when the vane was inserted further down $(\sim 32 \mathrm{~mm})$ suggesting that pockets of water were trapped within the sample. The $100 \% \mathrm{UO}_{2}$ sample had a well-defined settled layer and exhibited slightly higher shear strength values than at the 72 hour settling time. The shear strength of the sample did not reach the "as received" values

\footnotetext{
${ }^{18}$ February 2010 Monthly Status Report For PNNL Contracts Providing Technical Support to K Basin Closure and Sludge Treatment Projects, Pacific Northwest National Laboratory, Richland WA.

${ }^{19}$ March 2010 Monthly Status Report For PNNL Contracts Providing Technical Support to K Basin Closure and Sludge Treatment Projects, Pacific Northwest National Laboratory, Richland WA.
} 
initially measured. The $35 \% \mathrm{UO}_{2}: 65 \% \mathrm{UO}_{3} \cdot 2 \mathrm{H}_{2} \mathrm{O}$ also had a well defined settled layer and the shear strength values obtained were similar to the 72 hour settling data. Again the "as received" shear strength was not reproduced after $\sim 5$ weeks of settling.

The shear strength of the less than 500 micron small container composite (SCC) fraction of sludge samples collected from KE Engineered Containers SCS-CON-240, -250, and -260 have also been measured (PNNL-19035). There was insufficient sample available to adequately measure the shear strength of the sludge collected from Engineering Container SCS-CON-220. The samples identified as KW 240 SCC, KW 250 SCC and KW 260 SCC have estimated shear strengths of $300 \mathrm{~Pa}, 300 \mathrm{~Pa}$ and 79 $\mathrm{Pa}$, respectively. The results of the uranium oxide shear strength testing and the $2009 \mathrm{KE}$ Engineered Container shear strength testing and uranium speciation testing are summarized below in Table 6 .

Table 6 Results of mixed oxide shear strength in a pure uranium system

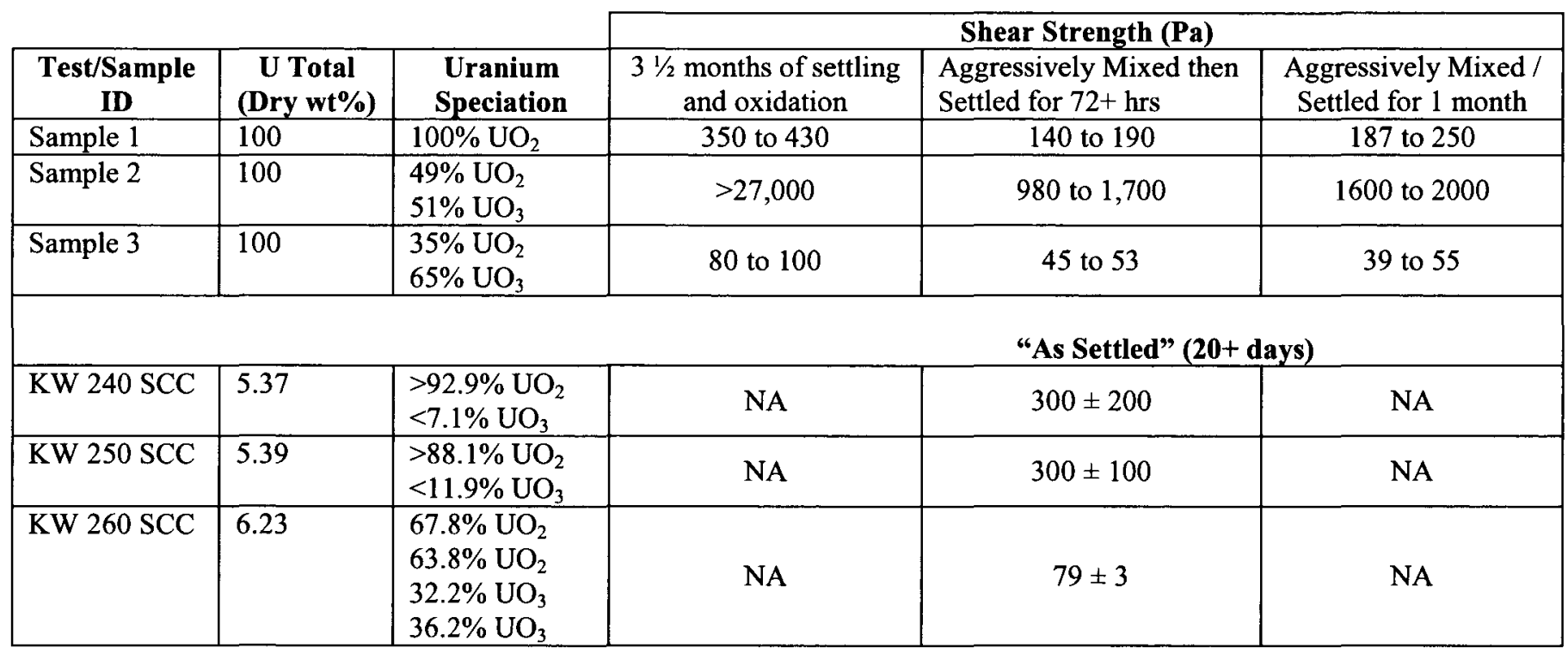

The results from Table 6 suggest that mixtures of uranium (IV) and uranium (VI) oxides produce maximum shear strength when the composition is roughly 50:50 (i.e., 50\% $\mathrm{UO}_{2}$ and 50\% $\mathrm{UO}_{3}$ ). PNNL staff state that the behavior of sample $2\left(\sim 50 \% \mathrm{UO}_{2}: 50 \% \mathrm{UO}_{3} \cdot 2 \mathrm{H}_{2} \mathrm{O}\right)$ has been observed before and was not unexpected. These results listed in Table 6 are plotted below in Figure 12 and shows that at roughly $50 \% \mathrm{U}(\mathrm{VI})$ conversion, the shear strength of the sample was at a maximum $(\sim 1,700 \mathrm{~Pa})$.

To date, the highest shear strength measurements for "actual" $\mathrm{K}$ Basin sludge samples were obtained after hydrothermal treatment for 7 to $10 \mathrm{hr}$ at $185^{\circ} \mathrm{C}$ at $225 \mathrm{psig}$ of high-uranium-content $\mathrm{KE}$ canister sludge. The unconfined compressive strength of samples from the hydrothermal testing, measured by a pocket penetrometer, infers that their shear strength may be between 120 and $170 \mathrm{kPa}$ (PNNL-16496). These short-duration hydrothermal tests were conducted at temperatures much greater than the projected maximum temperature of the T Plant canyon cells $\left(-7^{\circ} \mathrm{C}\right.$ to $\left.32^{\circ} \mathrm{C}\right)$; however, the strength results provide an initial bounding target for sludge stored for many years, and an upper range for simulants (53451TP02 Rev 0). 


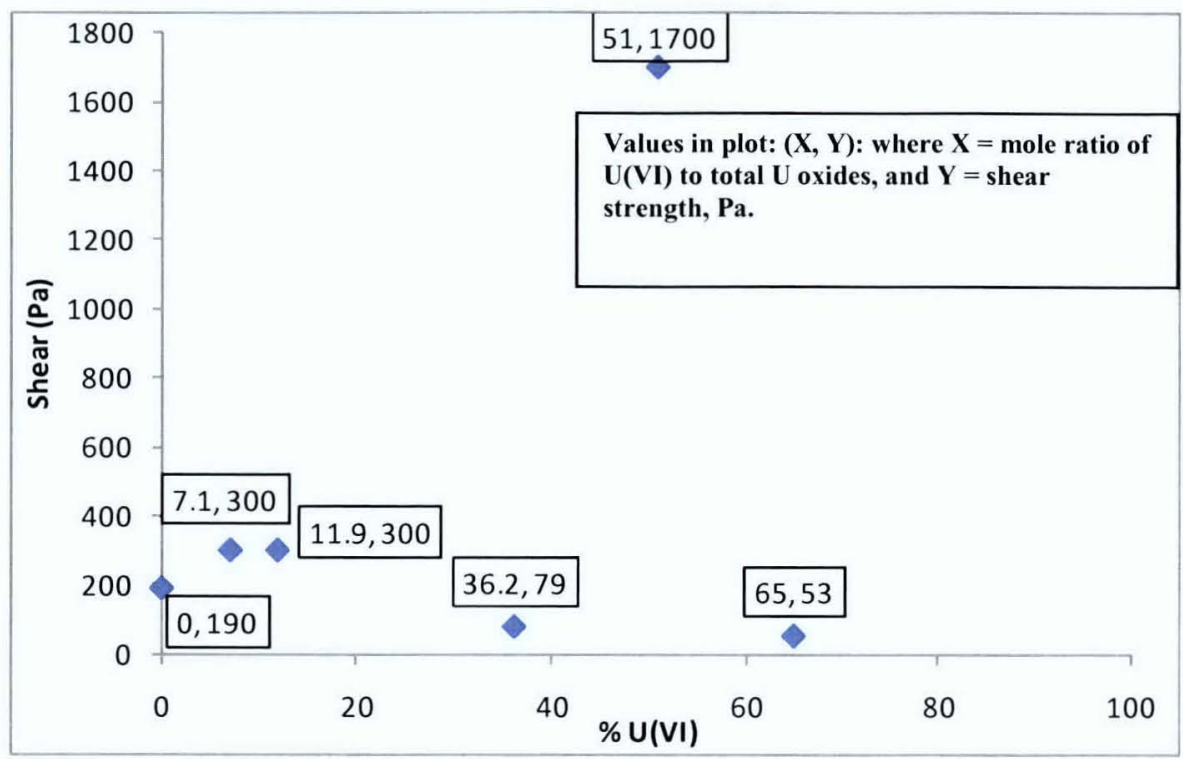

Figure 12 Correlation of Shear Strength with U(VI) concentration (Dry basis)

Plot of measured shear strength as a function of U(VI) wt $\%$ on a dry basis for three mixed uranium oxides samples and three KE and KW Engineered Container samples (see Table 6).

\subsection{Evaluation of Jet Erosion}

In a report by PNNL, Assessment of Jet Erosion for Potential Post-Retrieval K-Basin Settled Sludge (PNNL-18831), the bounding shear strength of the KE Basin sludge sample 96-13 was estimated. The KE Basin Canister sludge sample 96-13 was characterized as a heterogeneous material with noncohesive "chunks" being held together by a cohesive "paste". The estimated shear strength of the cohesive "paste" material is $3 \mathrm{kPa}$ to $5 \mathrm{kPa}$, and that of the non-cohesive "chunks" is $380 \mathrm{kPa}$ to 770 $\mathrm{kPa}$. The estimated bulk shear strength of sample 96-13 was determined to be $15 \mathrm{kPa}$ to $65 \mathrm{kPa}$. These shear strength measurements however are based on review of video taken when the 96-13 sample was removed from the graduated cylinder, used in the 28-month compaction and dry-out test. The shear strength was estimated based on video and "estimated applied forces, approximated contact areas, and the application of an estimate of the relation of compressive and shear stresses". Therefore, the results stated above should be considered qualitative, at best.

Recommendations in PNNL-18831 for future work include using a pocket penetrometer to quantify the shear strength of actual $\mathrm{K}$ Basin sludge samples in a hot cell environment. It is recommended that this method of determining shear strength be applied to homogeneous sludge samples, such that the results will be directly comparable to that obtained using a shear vane.

Current testing ${ }^{20}$ being performed at PNNL will determine the critical design parameters of a jet mobilization and retrieval tool such as nozzle dimensions, spray distance (distance from nozzle to sludge) and operation time for the effective Phase 2 mobilization and retrieval of agglomerated sludge from a STSC. This current testing will also determine the bounding conditions by which erosion occurs

\footnotetext{
${ }^{20}$ May 2010 Monthly Status Report For PNNL Contracts Providing Technical Support to K Basin Closure and Sludge Treatment Projects, Pacific Northwest National Laboratory, Richland WA.
} 
for both the larger non-cohesive "chunks" and the smaller cohesive "paste" fraction of agglomerated sludge. The results of the erosion study will give the STP critical information necessary for the design, procurement and implementation of an acceptable device for post interim storage sludge retrieval from the STSCs. A draft report of this work to evaluate erosion properties of high shear strength materials that are of both homogeneous and heterogeneous nature is planned to be issued later in FY 2010. 


\subsection{Physical Properties of Dried KE Engineered Container sludge and KW Engineered Container sludge}

Physical property characterization testing with sludge core samples from KW Engineered Container SCS-CON-220 in 2009 provides data on the behavior of agglomerates once dried out. Figure 13 and the associated text have been extracted from PNNL-19035 and demonstrate that the majority of solids selffractured when the samples dried out. This resulted in free-flowing granular material or friable solids that could be broken up with a small stainless steel spatula with little force. These images of KW Engineered Container sludge that have dried out during testing may indicate that if the sludge in the STSCs were to dry-out the resulting solids would be friable and self-fracture making them easily mobilized when re-wetted.

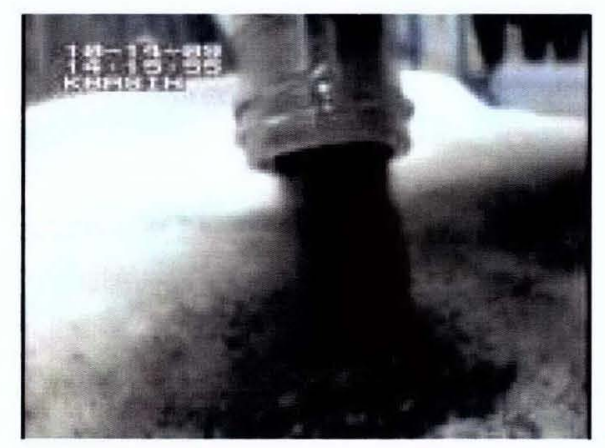

Sample TI004-1G (KW 220 Core A3)

(Free flowing powder)

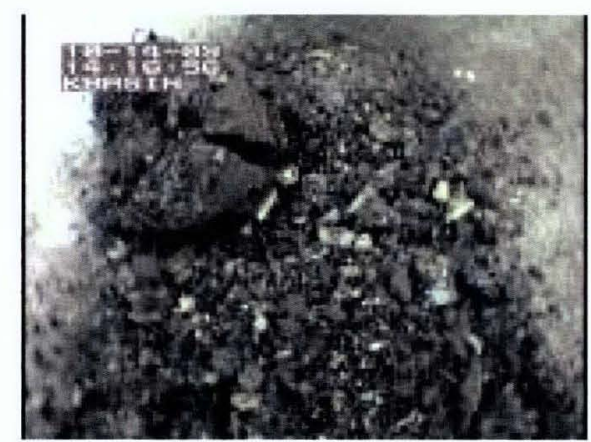

Sample TI004-1G (KW 220 Core A3)

(Large agglomerate in left corner of picture was the top fraction of the sample. The remainder of sample appears to have a high concentration of organic ion exchange resin).

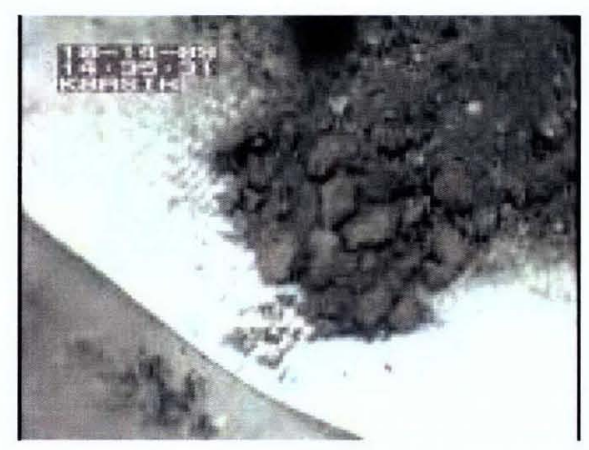

Sample TI004-2G (KW 220 Core B1)

(Agglomerates fractured with little force using a stainless steel spatula)

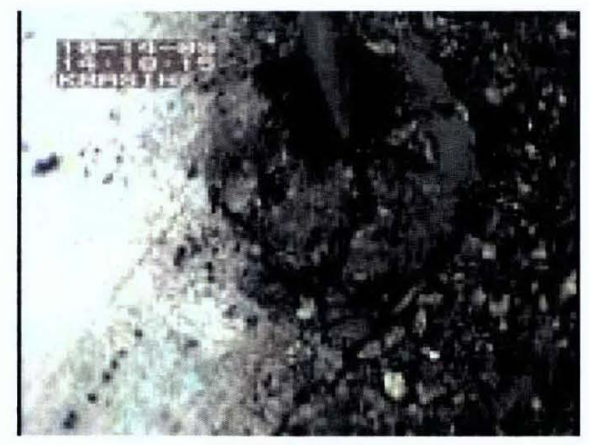

Sample TI004-1G ( KW 220 Core A3)

(Large agglomerate, seen in middle left picture, fractured with little force using $1-\mathrm{cm}$ wide stainless steel spatula)

Figure 13 Post-Test Examination of Physical Property Samples from SCS-CON-220 Core Samples 


\subsection{Conclusions and Recommendations}

The STP plans to store K Basin sludge in water filled STSCs at T Plant for at least 10 years prior to retrieval from the STSCs for final processing and disposal. The formation of high strength agglomerates, also known as "hard pan" or "hard packed" materials, while K Basin sludge is stored in the STSCs is of particular concern to the STP and is an issue that needs to be addressed prior to post interim storage activities.

Four instances of high strength agglomerate formation have been observed among samples collected from the KE Basin and stored in the PNNL hot cells. These four samples are designated 96-13, KC-2/3 M250, KC-2/3 SS and KE Pit. Six additional instances of "hardpan" or "hard packed" material have been observed while collecting samples from the KE Basin during the FY 1995 and FY 1999 sampling campaigns.

Analyses of these samples point toward a correlation between the level of homogeneity of the sludge and the formation of high strength agglomerates, as discussed in Section 3.4. In contrast, recent sampling of the KE and KW Engineered Container sludge in the KW Basin indicates that sludge of a more heterogeneous nature with respect to uranium content, like that observed in these samples, has not exhibited agglomeration (PNNL-19035). This process of agglomerate inhibition via the influence of non-uranium constituents is discussed in Section 3.5 and illustrated in Figure 9. This correlation is further validated by preliminary results of uraninite oxidation testing performed at PNNL, which supports the conclusion that the more heterogeneous $\mathrm{KE}$ and $\mathrm{KW}$ Engineered Container sludge has little perceptible strength, as discussed in Section 3.5.

In addition to total uranium content and sample homogeneity, the data show a weak correlation between sludge storage conditions and the formation of agglomerates, as discussed in Section 3.4. However, of the conditions that the data show lead to agglomerate formation mentioned above, storage time is the most influential, as discussed in Section 3.4. For example, the four samples mentioned above that have exhibited severe agglomeration and self-cementation had been in PNNL hot cell storage for a period of 6 to 8 years.

The actual physiochemical mechanism(s) of high strength $\mathrm{K}$ Basin agglomerate formation is not known. However several commonalities and proposed mechanisms that likely participate in this phenomenon are the formation of floating uranium (VI) aggregates or loose flocculents, and ultimately agglomerates at the air-water interface, rhythmic precipitation of metaschoepite and other uranium (VI) compounds forming "Liesegang Bands" at the sludge-water interface and Ostwald ripening seen in many crystal formation mechanisms. Accelerated uraninite oxidation testing currently being performed by PNNL will provide the STP with further insight into agglomerate formation mechanisms. It is highly recommended that the STP revisit this consolidation of information on agglomerate formation when the final uraninite $\left(\mathrm{UO}_{2}\right)$ oxidation report is released later in FY 2010.

There is a possibility of high strength agglomerates self-cementing inside storage vessels, and the shear strength and erosion properties of these materials need to be studied and quantified. One study performed by PNNL provides the STP with a rough estimate of the shear strength of sample 96-13 and assessed the potential for using a jet erosion method to erode and mobilize agglomerates (PNNL-18831). The shear strength of this sample was estimated to be $15 \mathrm{kPa}$ to $65 \mathrm{kPa}$ for the bulk material. This value was much higher for the non-cohesive "chunks" (380 kPa to $770 \mathrm{kPa})$ and much lower for the cohesive 
"paste" ( $3 \mathrm{kPa}$ to $5 \mathrm{kPa}$ ) materials, as discussed in Section 4.2. Current unpublished work by PNNL will determine the critical retrieval tool design parameters and erosion properties of high strength agglomerated sludge. It is recommended that the STP use this information to aid in the design and testing of an acceptable Phase 2 sludge retrieval tool. A draft report of this work is planned to be issued later in FY 2010. 
PRC-STP-00274, revision 1

\subsection{References}

Delegard, et al., 2009, Preliminary Status: Uraninite Oxidation by Oxygen Gas at $50^{\circ} \mathrm{C}$, Pacific Northwest National Laboratory, Richland WA.

D.W. Shoesmith, 2000, “Fuel corrosion processes under waste disposal conditions", Journal of Nuclear Materials 282 (2000) $1-31$.

February 2010 Monthly Status Report For PNNL Contracts Providing Technical Support to K Basin Closure and Sludge Treatment Projects, Pacific Northwest National Laboratory, Richland WA.

HNF-4746, 1999a (Pitner, 1999a), K East Basin Sludge Sampling/1999 Campaigns, Fluor Hanford, Richland WA.

HNF-6705, 2000, Observations of K Basins Sludge Behavior in Relation to Sludge Container Design and Storage at T Plant, Fluor Hanford, Richland WA.

HNF-SD-SNF-TI-015, Vol 2, Rev 14A, 2009, Spent Nuclear Fuel Project Technical Databook, CH2MHILL Plateau Remediation Company, Richland WA.

HNF-SP-1201, 1997, Analysis of Sludge from Hanford K East Basin Canisters, DE\&S Hanford, Inc, Richland WA.

July 2009 Monthly Status Report For PNNL Contracts Providing Technical Support to K Basin Closure and Sludge Treatment Projects, Pacific Northwest National Laboratory, Richland WA.

March 2010 Monthly Status Report For PNNL Contracts Providing Technical Support to K Basin Closure and Sludge Treatment Projects, Pacific Northwest National Laboratory, Richland WA.

Onishi, Y., 2010, 53451-TP02 Rev 0, Correlating Durham Geo Pocket Penetrometer Unconfined Compressive Strength To Shear Strength for Sludge Agglomerate Strength Evaluation, Pacific Northwest National Laboratory, Richland, WA.

PNNL-12108, 1998, Evaluation of Ion Exchange Materials in K Basin Floor Sludge and Potential Solvents for PCB Extraction from Ion Exchange Materials, Pacific Northwest National Laboratory, Richland, WA.

PNNL-14228, 2003, Updated Volumetric Expansion Factors for K Basin Sludge During Storage, Pacific Northwest National Laboratory, Richland, WA.

PNNL-13320, 2000, Gas Generation form K East Basin Sludge - Series I Testing, Pacific Northwest National Laboratory, Richland, WA.

PNNL-14306, 2004, Alternative Conceptual Model for Colloid Generation from Commercial Spent Nuclear Fuel, Pacific Northwest National Laboratory, Richland WA. 
PNNL-14346, 2003, Gas Generation from K East Basin Sludges and Irradiated Metallic Uranium Fuel Particles - Series III Testing, Pacific Northwest National Laboratory, Richland WA.

PNNL-15092, 2005, Characterization of Compaction and Dryout Properties of KE Basin Sludge During Long-Term Storage, Pacific Northwest National Laboratory, Richland WA.

PNNL-16496, 2007, Hydrothermal Testing of K Basin Sludge and N Reactor Fuel at Sludge Treatment Project Operating Conditions, Pacific Northwest National Laboratory, Richland WA.

PNNL-17078 (Letter Report 54351-RPT01), 2007, Characteristics of K East Basin Sludge Samples Archived in the RPL, Pacific Northwest National Laboratory, Richland WA.

PNNL-17678, 2008, Preparation and Characterization of Uranium Oxides in Support of the K Basin Sludge Treatment Project, Pacific Northwest National Laboratory, Richland WA.

PNNL-18831, 2009, Assessment of Jet Erosion for Potential Post-Retrieval K-Basin Settled Sludge, Pacific Northwest National Laboratory, Richland WA.

PNNL-19035, 2009, Characterization Data Package for Containerized Sludge Samples Collected from Engineered Containers SCS-CON-240, 250, 260, and 220, Pacific Northwest National Laboratory, Richland WA.

PRC-STP-00113, 2010, Sludge Treatment Project Engineered Container Retrieval and Transfer System Technology Maturation Plan, T. K. Dhaliwal, CH2MHILL Plateau Remediation Company, Richland WA

PRC-STP-00162, 2009, Thermal and Gas Analyses for STSC Loaded with Settler Sludge, M. G. Plys Fauske and Associates LLC and M. E. Johnson. CH2M HILL Plateau Remediation Company, Richland, WA.

PRC-STP-00212, 2010, Screening Evaluation of Characterization Data for Engineered Container SCSCON-220, -240, -250, and -260, M. E. Johnson, CH2MHILL Plateau Remediation Company, Richland WA.

PRC-STP-00220, 2010, Sludge Treatment Project Engineered Container Retrieval and Transfer System - Thermal and Gas Analyses for STSC Loaded with KW Engineered Container Sludge, M. G. Plys et al Fauske and Associates LLC and M. E. Johnson. CH2M HILL Plateau Remediation Company, Richland, WA.

Shimskey, R. W., June 2010, 53451-TI-8, Long-Term Storage Evaluation of K Basin Sludge Archive Samples, Pacific Northwest National Laboratory, Richland WA.

WHC-EP-0877, 1995, K Basin Corrosion Program Report, Westinghouse Hanford Company, Richland WA.

WHC-SP-1 182, 1996, Analysis of Sludge from Hanford K East Basin Floor and Weasel Pit, Westinghouse Hanford Company, Richland WA. 


\section{Appendix A Sludge Sample Observation Table.}

\begin{tabular}{|c|c|c|c|c|c|c|c|c|c|}
\hline $\begin{array}{l}\text { Sample } \\
\text { ID }\end{array}$ & Sample Type & $\begin{array}{l}\text { Date Collected/ } \\
\text { prepared }\end{array}$ & $\begin{array}{l}\text { Storage /Test } \\
\text { Temperature }{ }^{\circ} \mathrm{C}\end{array}$ & Duration & $\begin{array}{l}\text { Agglomeration } \\
\text { Strength }\end{array}$ & $\begin{array}{l}\text { Uranium } \\
\text { Total, wt \% } \\
\text { dry }\end{array}$ & $\begin{array}{l}\text { Starting } \\
\text { Uranium } \\
\text { Phases }^{21,12} \\
\end{array}$ & $\begin{array}{l}\text { Ending } \\
\text { Uranium } \\
\text { Phases }^{22,11} \\
\end{array}$ & Misc. Comments \\
\hline FE-5 & KE Weasel Pit & 1999 & 31 to 38 & 28 month & Insignificant & 5.32 & $\begin{array}{c}\text { None } \\
\text { detected }\end{array}$ & Uranophane (L) & \\
\hline $\begin{array}{c}\mathrm{KC}-2 / 3 \\
\text { whole }\end{array}$ & $\begin{array}{l}\text { KE Canister sludge } \\
\text { composite from all } \\
\text { three bays }\end{array}$ & 1999 & 31 to 38 & 28 month & Insignificant & 59.0 & $\mathrm{Sc}, \mathrm{Ur}$ & $\begin{array}{c}\text { Metaschoepite } \\
(\mathrm{H}) \text {, schoepite } \\
(\mathrm{H})\end{array}$ & \\
\hline $\begin{array}{c}\mathrm{KC}-2 / 3 \\
\mathrm{M} 250\end{array}$ & $\begin{array}{l}\text { "Minus" } 250 \mu \mathrm{m} \\
\text { fraction of KC- } 2 / 3 \\
\text { whole (KE Canister } \\
\text { sludge composite) }\end{array}$ & 1999 & $\sim 34$ & $\begin{array}{l}\sim 8 \text { years in } \\
\text { PNNL Hot } \\
\text { Cells }\end{array}$ & Not measured & 68.3 & $\begin{array}{l}\mathrm{Ur}(\mathrm{H}), \mathrm{MSc} \\
(\mathrm{M})\end{array}$ & $\begin{array}{c}\text { Metaschoepite } \\
\text { (H) }\end{array}$ & $\begin{array}{l}\text { Subsample prepared } \\
\text { shortly after collection in } \\
1999 \text { by wet sieving to } \\
\text { obtain a "Plus" } 250 \mu \mathrm{m} \\
\text { fraction and a "Minus" } \\
250 \mu \mathrm{m} \text { fraction". }\end{array}$ \\
\hline $\mathrm{KC}-2 / 3 \mathrm{SS}$ & $\begin{array}{l}\text { Settled Solids Fraction } \\
\text { of KC-2/3 whole }\end{array}$ & 1999 & -34 & $\begin{array}{l}\sim 8 \text { years in } \\
\text { PNNL Hot } \\
\text { Cells }\end{array}$ & Not Measured & 59.0 & $\begin{array}{c}\text { Not } \\
\text { Measured }\end{array}$ & & \\
\hline KE-Pit & $\begin{array}{l}\text { Weasel Pit Sludge } \\
\text { Sample }\end{array}$ & 1999 & $\sim 34$ & $\begin{array}{l}\sim 8 \text { years in } \\
\text { PNNL Hot } \\
\text { Cells }\end{array}$ & Not Measured & 7.99 & $\begin{array}{c}\text { Not } \\
\text { Measured }\end{array}$ & & \\
\hline $\begin{array}{c}\mathrm{KC}-4 \\
\text { (whole) }\end{array}$ & $\begin{array}{l}\text { KE Floor sludge } \\
\text { between canisters } \\
\text { (Composite sample) }\end{array}$ & 1999 & 31 to 38 & 28 month & Insignificant & 16.6 & $\begin{array}{c}\text { Not } \\
\text { Measured }\end{array}$ & $\begin{array}{c}\text { Schoepite }(\mathrm{M}) \text {, } \\
\text { sodium uranyl } \\
\text { oxide } \\
\text { hydroxide }(\mathrm{M}), \\
\operatorname{Be}(\mathrm{H})\end{array}$ & \\
\hline $\mathrm{KC}-5$ & $\begin{array}{l}\text { KE Floor sludge from } \\
\text { main basin (Composite } \\
\text { sample) }\end{array}$ & 1999 & 31 to 38 & 28 month & Insignificant & 6.36 & $\begin{array}{c}\mathrm{Be}, \mathrm{Sc} \text { (KC-5 } \\
\text { P250 only) }\end{array}$ & $\begin{array}{l}\mathrm{Be}(\mathrm{H}) \text { from } \\
\mathrm{KC} \text { Floor Comp }\end{array}$ & $\begin{array}{c}\text { KC-5 (Sub-sample of } \\
\text { KC-4 whole) }\end{array}$ \\
\hline $\begin{array}{l}96-13 \\
\text { (solid } \\
\text { grad) }\end{array}$ & KE Canister sludge & 1996 & 31 to 38 & 28 month & $\begin{array}{c}\text { monolithic } \\
15 \text { to } 65 \mathrm{kPa} \\
\text { PNNL-18831 }\end{array}$ & 82.0 & Ur & $\begin{array}{l}\text { Metaschoepite, } \\
\text { schoepite }\end{array}$ & $\begin{array}{l}\text { Sample experienced a } \\
\text { complete loss of } \\
\text { supernatant while in } \\
\text { storage, prior to testing. }\end{array}$ \\
\hline $\begin{array}{l}\text { SNF- } \\
\text { Comp }\end{array}$ & $\begin{array}{l}\text { Floor, canister, and } \\
\text { crushed fuel mix } \\
\text { (Composite sample) }\end{array}$ & 1999 & 31 to 38 & 28 month & Insignificant & 60.2 & $\mathrm{Be}, \mathrm{Sc}, \mathrm{Ur}$ & Not Measured & $\begin{array}{l}\text { Original sample name } \\
\text { SNF-Comp 60S-PG }\end{array}$ \\
\hline KE NLOP & North Loadout Pit & 2003 & 31 to 38 & 28 month & Insignificant & 2.51 & $\begin{array}{c}\text { None } \\
\text { Detected }\end{array}$ & Metaschoepite & \\
\hline
\end{tabular}

\footnotetext{
${ }^{21}$ Starting U Phases data taken from Table 2.2, PNNL-15092 for all samples excluding KC-2/3 M250

22 Ending U Phases data taken from Table 6 of PNNL-17078, 2007

${ }^{23} \mathrm{XRD}$ was performed on sample 96-13 in 2007, 3 years after conducting the long-term settling test (PNNL-17078)

${ }^{12} \mathrm{KC}-2 / 3 \mathrm{M} 250$ ending uranium phases identified as metaschoepite (PNNL-16496, Table 3.3)
} 